Article

\title{
Special Low Protein Foods in the UK: An Examination of Their Macronutrient Composition in Comparison to Regular Foods
}

\author{
Georgina Wood ${ }^{1, *}$, Sharon Evans ${ }^{2}$, Kiri Pointon-Bell ${ }^{1}$, Júlio César Rocha ${ }^{3,4}$ (i) and \\ Anita MacDonald ${ }^{2}$ \\ 1 Faculty of Health, Education \& Life Sciences, Birmingham City University, City South Campus, \\ Westbourne Road, Edgbaston, Birmingham B15 3TN, UK; Kiri.Pointon-Bell@bcu.ac.uk \\ 2 Birmingham Women's and Children's NHS Foundation Trust, Steelhouse Lane, Birmingham B4 6NH, UK; \\ sharon.morris6@nhs.net (S.E.); Anita.Macdonald@nhs.net (A.M.) \\ 3 Nutrition \& Metabolism, NOVA Medical School, Faculdade de Ciências Médicas, \\ Universidade Nova de Lisboa, Campo Mártires da Pátria, 130, 1169-056 Lisbon, Portugal; \\ rochajc@nms.unl.pt \\ 4 Center for Health Technology and Services Research (CINTESIS), R. Dr. Plácido da Costa, s/n, \\ 4200-450 Porto, Portugal \\ * Correspondence: georgiewood93@googlemail.com
}

Received: 29 May 2020; Accepted: 23 June 2020; Published: 25 June 2020

\begin{abstract}
Special low protein foods (SLPFs) are essential in a low phenylalanine diet for treating phenylketonuria (PKU). With little known about their nutritional composition, all SLPFs on UK prescription were studied $(n=146)$ and compared to equivalent protein-containing foods $(n=190)$. SLPF nutritional analysis was obtained from suppliers/manufacturers. Comparable information about regular protein-containing foods was obtained from online UK supermarkets. Similar foods were grouped together, with mean nutritional values calculated for each subgroup $(n=40)$ and percentage differences determined between SLPFs and regular food subgroups. All SLPF subgroups contained $43-100 \%$ less protein than regular foods. Sixty-three percent $(n=25 / 40)$ of SLPF subgroups contained less total fat with palm oil $(25 \%, n=36 / 146)$ and hydrogenated vegetable oil $(23 \%, n=33 / 146)$ key fat sources. Sixty-eight percent $(n=27 / 40)$ of SLPF subgroups contained more carbohydrate, with $72 \%$ ( $n=105 / 146)$ containing added sugar. Key SLPF starch sources were maize/corn $(72 \% ; n=105 / 146)$. Seventy-seven percent $(n=113 / 146)$ of SLPFs versus $18 \%(n=34 / 190)$ of regular foods contained added fibre, predominantly hydrocolloids. Nine percent of SLPFs contained phenylalanine $>25 \mathrm{mg} / 100 \mathrm{~g}$ and sources of phenylalanine/protein in their ingredient lists. Stricter nutritional composition regulations for SLPFs are required, identifying maximum upper limits for macronutrients and phenylalanine, and fat and carbohydrate sources that are associated with healthy outcomes.
\end{abstract}

Keywords: phenylketonuria; special low protein foods; nutritional composition; UK; macronutrients

\section{Introduction}

In phenylketonuria (PKU), the only UK treatment option is a rigorous low phenylalanine diet that is essential to prevent neurotoxicity and irreversible brain damage [1]. Most patients with classical PKU tolerate $<10 \mathrm{~g}$ natural protein daily [2], with up to $80 \%$ of daily protein provided by minimal phenylalanine-containing protein substitutes which are derived from either L-amino acids or glycomacropeptide. Special low protein foods (SLPFs) are an integral part of dietary treatment. They contribute essential energy (up to $50 \%$ of intake), variety and bulk, helping to improve or maintain 
metabolic control and growth [3-5]. Given their importance in a low protein diet, their nutritional profile and food labelling should receive the same care and attention as regular foods.

The composition and labelling of SLPFs is regulated by European Commission (EC) legislation on "dietary foods for special medical purposes" [6]. It gives no guidance on the source, amount or even quality of the carbohydrate and fat added to SLPFs [6]. The EC and UK regulations require SLPFs to list the amounts of energy, carbohydrate (including sugars), fat, protein and salt per $100 \mathrm{~g}$ [6-9] but no upper nutrient limits are defined. As a consequence of protein removal, it is expected that lower protein foods will contain higher amounts of carbohydrate and possibly fat $[4,10,11]$, but there is no research describing the nutritional composition of UK SLPFs.

Considering that SLPFs receive minimal regulation, and with limited research into their nutritional profile, it has been suggested that a detailed analysis of each country's SLPFs be conducted $[4,10]$. The present study aimed to analyse the nutritional composition of all SLPFs available by the Advisory Committee of Borderline Substances (ACBS) prescription system in the UK.

\section{Materials and Methods}

From January-May 2019, detailed nutritional composition data for all UK SLPFs available on ACBS prescription was collected from manufacturers and suppliers. Data was obtained from company websites or from information sheets provided directly from the companies. Nutritional data was obtained per $100 \mathrm{~g} / 100 \mathrm{~mL}$ and per serving for cooked and dried weight of products for: energy, protein, phenylalanine, total carbohydrate, sugars, fibre, total fat, saturated fat and salt. If nutritional data was stated as less than a certain value, e.g., " $<0.1$ " or " $<0.5$ ", 0.001 was deducted from these numbers and values of "0.099" or "0.499" were used. Product ingredients, sources of added fibre, starch, sugar, fat and phenylalanine were obtained. Information was stored on an excel spreadsheet. Products were divided into 10 groups in a similar way to Pena and colleagues [10], and included: bread products (bread, pizza bases), pasta/rice/noodles, flour/mixes, meat/meat replacers, breakfast products (cereals and bars), eggs/egg replacers, milk/milk replacers, snacks (biscuits, cakes, crisps, chocolate, rusks, hazelnut spread and crackers), desserts (rice pudding, flavoured desserts, yogurt, and jelly) and other snacks/meals (soups, potato cakes, cheese sauce and potato pots). These groups were then categorised into 40 subgroups of equivalent product types, e.g., burgers, sausages, cookies/biscuits, cake mixes. The mean and range values for every nutrient across subgroups of similar products were calculated.

The same information (except for sources of phenylalanine) was collected and calculated for at least 2 regular protein-containing comparable foods per subgroup, from major UK supermarkets with nutritional analysis data online (ASDA, Morrisons, Sainsburys, Tesco, Waitrose, Ocado and Marks \& Spencer). Phenylalanine content was estimated by calculating that $1 \mathrm{~g}$ of protein contained $50 \mathrm{mg}$ phenylalanine [12]. Taste, texture, recipe ingredients and food function were considered when choosing comparator foods. Where possible, only regular products that had nutritional analysis available in the same format as SLPFs were considered, e.g., dried format or after preparation. Percentage differences between SLPFs and regular foods for all mean nutritional values were then determined. Variations of $\pm 0-10 \%$ were considered comparable.

\section{Results}

One hundred and fifty one SLPFs were identified on UK ACBS prescription. One SLPF was undergoing reformulation and regular comparators for four SLPFs were not available. Thus, 146 SLPFs were compared with 190 regular products. Appendix A displays all SLPF and regular product subgroups $(n=40)$ and the investigated variables.

\subsection{Energy}

Mean energy content (per $100 \mathrm{~g}$ ) for all SLPFs ( $n=146$ ) was $292 \mathrm{kcal}$ (range: 32-583 kcal) and for all regular foods ( $n=190)$ was $298 \mathrm{kcal}$ (range: $26-558 \mathrm{kcal})$. Energy content was comparable for $50 \%$ of the subgroups of products $(n=20 / 40)$. For SLPFs, mean energy values for low protein hazelnut 
spread, prepared sausage mixes, prepared burger mixes, egg white and egg replacers were $37-66 \%$ lower than regular varieties. Low protein dessert pots, hot breakfast cereals, potato pots and fish substitutes contained 36-41\% more energy than regular versions.

\subsection{Protein and Phenylalanine}

All SLPF subgroups contained between 43-100\% less protein and 60-100\% less phenylalanine than regular foods. Table 1 displays the mean and range for phenylalanine content and sources of phenylalanine for all SLPF subgroups. The main sources of phenylalanine found in SLPFs were milk (including milk protein) (32\% of SLPFs; $n=47 / 146)$ and yeast (14\% of SLPFs; $n=21 / 146)$. For 91\% of SLPFs ( $n=133 / 146)$, the phenylalanine content was either $\leq 25 \mathrm{mg}$ per $100 \mathrm{~g}$ or no sources of phenylalanine/protein were identified in the product ingredient list (Table 1).

Table 1. Phenylalanine content and identified sources of natural protein for all special low protein food (SLPF) subgroups. Values displayed as mean (range).

\begin{tabular}{|c|c|c|}
\hline SLPF Subgroup & $\begin{array}{l}\text { Phenylalanine (mg) } \\
\text { per } 100 \mathrm{~g} \text { of Product }\end{array}$ & $\begin{array}{c}\text { Identified Sources of Natural } \\
\text { Protein/Phenylalanine in Each SLPF Subgroup }\end{array}$ \\
\hline Bread $(n=13)$ & $15(8-30)$ & $\begin{array}{l}\text { Yeast }(n=13) \text {, fennel seeds }(n=1) \text {, anis seeds } \\
\qquad(n=1)\end{array}$ \\
\hline Pizza base $(n=2)$ & $13(2-24)$ & Yeast $(n=2)$ \\
\hline Pasta/rice/noodles $(n=33)$ & $13(8-25)$ & Rice flour $(n=5)$ \\
\hline Pasta and sauces (prepared) $(n=5)$ & $8(3-14)$ & $\begin{array}{l}\text { Milk }(n=4), \text { yeast extract }(n=1) \\
\text { cheese powder }(n=1)\end{array}$ \\
\hline Risotto $(n=1)$ & 6 & Milk $(n=1)$ \\
\hline xPots/pot noodles (prepared) $(n=4)$ & $9(6-15)$ & Peas (dried) $(n=1)$, milk $(n=4)$ \\
\hline Bread mix $(n=3)$ & $15(4-20)$ & Yeast $(n=1)$ \\
\hline Cake mix $(n=4)$ & $14(4-30)$ & Cocoa powder $(n=1)$, cocoa $(n=1)$ \\
\hline Flour $(n=4)$ & $5(4-<10)$ & No sources identified \\
\hline Pancake/waffle mix $(n=1)$ & 22 & No sources identified \\
\hline Pizza mix $(n=1)$ & $<31$ & No sources identified \\
\hline Egg replacer (dried mix) $(n=3)$ & $7(<5-10)$ & No sources identified \\
\hline Egg white replacer $(n=1)$ & Nil added & No sources identified \\
\hline Milk (liquid) $(n=4)$ & $6(0-10)$ & Milk $(n=4)$, whey powder $(n=2)$ \\
\hline Milk (powder) $(n=1)$ & 20 & Milk $(n=1)$, whey permeate $(n=1)$ \\
\hline Burgers (prepared) $(n=3)$ & $25(16-31)$ & Milk $(n=2)$, yeast $(n=1)$ \\
\hline Fish substitute (prepared) $(n=1)$ & 38 & $\begin{array}{c}\text { Shrimps }(n=1), \operatorname{cod}(n=1), \text { rice flour }(n=1), \\
\operatorname{milk}(n=1)\end{array}$ \\
\hline Sausages (prepared) $(n=3)$ & $33(29-38)$ & Milk $(n=3)$, potato flake $(n=3)$ \\
\hline Breakfast bar $(n=4)$ & $17(12-25)$ & Milk $(n=4)$, cocoa powder $(n=1)$ \\
\hline Breakfast cereal (dried) $(n=3)$ & $12(6-22)$ & Cocoa powder $(n=1)$ \\
\hline Fruit bar $(n=1)$ & 16 & $\operatorname{Egg}(n=1)$ \\
\hline $\begin{array}{c}\text { Hot breakfast cereal } \\
\text { (prepared with water) }(n=4)\end{array}$ & $4(2-6)$ & Cocoa powder $(n=1)$, milk $(n=4)$ \\
\hline Biscuits/cookies $(n=9)$ & $10(1-27)$ & Cocoa mass $(n=1), \operatorname{egg}(n=1)$, cocoa $(n=2)$ \\
\hline Cake $(n=3)$ & $6(6-6)$ & No sources identified \\
\hline Chocolate $(n=2)$ & $12(<10-14)$ & $\begin{array}{l}\text { Milk }(n=1) \text {, cocoa powder }(n=1) \\
\text { carob flour }(n=1)\end{array}$ \\
\hline Crackers $(n=3)$ & $12(10-17)$ & No sources identified \\
\hline Crisps $(n=4)$ & $16(8-22)$ & $\begin{array}{l}\text { Wheat flour }(n=2) \text {, rice flour }(n=1) \text {, whey } \\
\text { powder }(n=2) \text {, yeast extract powder }(n=1) \text {, } \\
\text { cheese powder }(n=1) \text {, yeast powder }(n=1)\end{array}$ \\
\hline Crispbread crackers $(n=1)$ & 6 & Pea starch $(n=1)$ \\
\hline
\end{tabular}


Table 1. Cont.

\begin{tabular}{|c|c|c|}
\hline SLPF Subgroup & $\begin{array}{l}\text { Phenylalanine }(\mathrm{mg}) \\
\text { per } 100 \mathrm{~g} \text { of Product }\end{array}$ & $\begin{array}{c}\text { Identified Sources of Natural } \\
\text { Protein/Phenylalanine in Each SLPF Subgroup }\end{array}$ \\
\hline French toast crackers $(n=1)$ & 30 & Baker's yeast $(n=1)$ \\
\hline Hazelnut spread $(n=1)$ & 19 & $\begin{array}{l}\text { Milk }(n=1), \text { hazelnuts }(n=1), \text { almonds }(n=1) \text {, } \\
\text { cocoa paste }(n=1)\end{array}$ \\
\hline Rusks $(n=1)$ & 4 & $\operatorname{Milk}(n=1)$ \\
\hline Dessert pot $(n=2)$ & $<4$ & No sources identified \\
\hline Flavoured desserts (prepared) $(n=4)$ & $5(1-13)$ & Milk $(n=4)$, chocolate powder $(n=1)$ \\
\hline Jelly (dried) $(n=2)$ & $<2$ & No sources identified \\
\hline Rice pudding $(n=4)$ & $6(5-8)$ & Milk $(n=4)$ \\
\hline Yogurt (prepared) $(n=1)$ & 2 & No sources identified \\
\hline Cheese sauce (prepared) $(n=1)$ & 13 & Milk $(n=1)$ \\
\hline Potato cakes (prepared) $(n=1)$ & 46 & Potato flake $(n=1)$ \\
\hline Potato pots/Smash (prepared) $(n=3)$ & $25(23-27)$ & Potato flake $(n=3)$, milk $(n=3)$ \\
\hline Soup (prepared) $(n=4)$ & $2(1-2)$ & Milk $(n=4)$, peas $(n=2)$ \\
\hline
\end{tabular}

\subsection{Carbohydrate (Including Sugars)}

Overall, the carbohydrate content was higher in $68 \%(n=27 / 40)$ of SLPF subgroups when compared to protein-containing foods, with the greatest differences for meat, fish and egg substitutes (281-9167\%).

The percentage of foods containing added sugar is given in Figure 1. Only $35 \%(n=14 / 40)$ of SLPF subgroups contained higher amounts of sugar with $45 \%(n=18 / 40)$ containing less than regular foods. Fish substitute contained $1000 \%$ more sugar than regular fish, but the amount of sugar was small (sugar content in fish substitute $1.1 \mathrm{~g} / 100 \mathrm{~g}$ ). Low protein pizza bases, flour and breakfast cereals contained only 3-22\% more total carbohydrate than regular foods, but $81-273 \%$ more sugar.

Over $70 \%(72 \% ; n=105 / 146)$ of SLPFs compared with $66 \%(n=125 / 190)$ of regular foods contained an added sugar source (Figure 1), with low protein bread, milk and meat replacements commonly adding sugar where regular foods did not. Key sugar sources in both groups are given in Table 2.

Table 2. Key sources of added sugar identified from ingredient lists for SLPFs and regular protein-containing foods.

\begin{tabular}{ccc}
\hline $\begin{array}{c}\text { Key Sources of } \\
\text { Added Sugar }\end{array}$ & \% of SLPF $(\boldsymbol{n}=\mathbf{1 4 6})$ & $\begin{array}{c}\text { \% of Regular Protein Containing Foods } \\
(\boldsymbol{n}=\mathbf{1 9 0})\end{array}$ \\
\hline Sugar & $52 \%(n=76 / 146)$ & $58 \%(n=111 / 190)$ \\
Glucose & $29 \%(n=43 / 146)$ & $23 \%(n=44 / 190)$ \\
Maltodextrin & $23 \%(n=33 / 146)$ & $13 \%(n=25 / 190)$ \\
Dextrose & $15 \%(n=22 / 146)$ & $12 \%(n=22 / 190)$ \\
Sucrose & $3 \%(n=5 / 146)$ & $1 \%(n=2 / 190)$ \\
Fructose & $<1 \%(n=1 / 146)$ & $6 \%(n=12 / 190)$ \\
\hline
\end{tabular}

Maize/corn and potato starch were the main types of starch used in SLPFs. Over $70 \%(n=105 / 146)$ of SLPFs contained maize/corn starch whereas $56 \%(n=82 / 146)$ included potato starch. Fifty-four percent $(n=79 / 146)$ of SLPFs contained both starches. Maize/corn starch was common in low protein pasta, rice and noodles $(100 \% ; n=43 / 43)$ and snacks $(80 \% ; n=20 / 25)$. In contrast, the most common starch sources identified in regular foods were wheat flour $(n=82 / 190)$; wheat semolina $(n=30 / 190)$ and rice or rice flour $(n=27 / 190)$. Maize/corn starch and potato starch were only listed in $13 \%(n=24 / 190)$ of regular foods. 


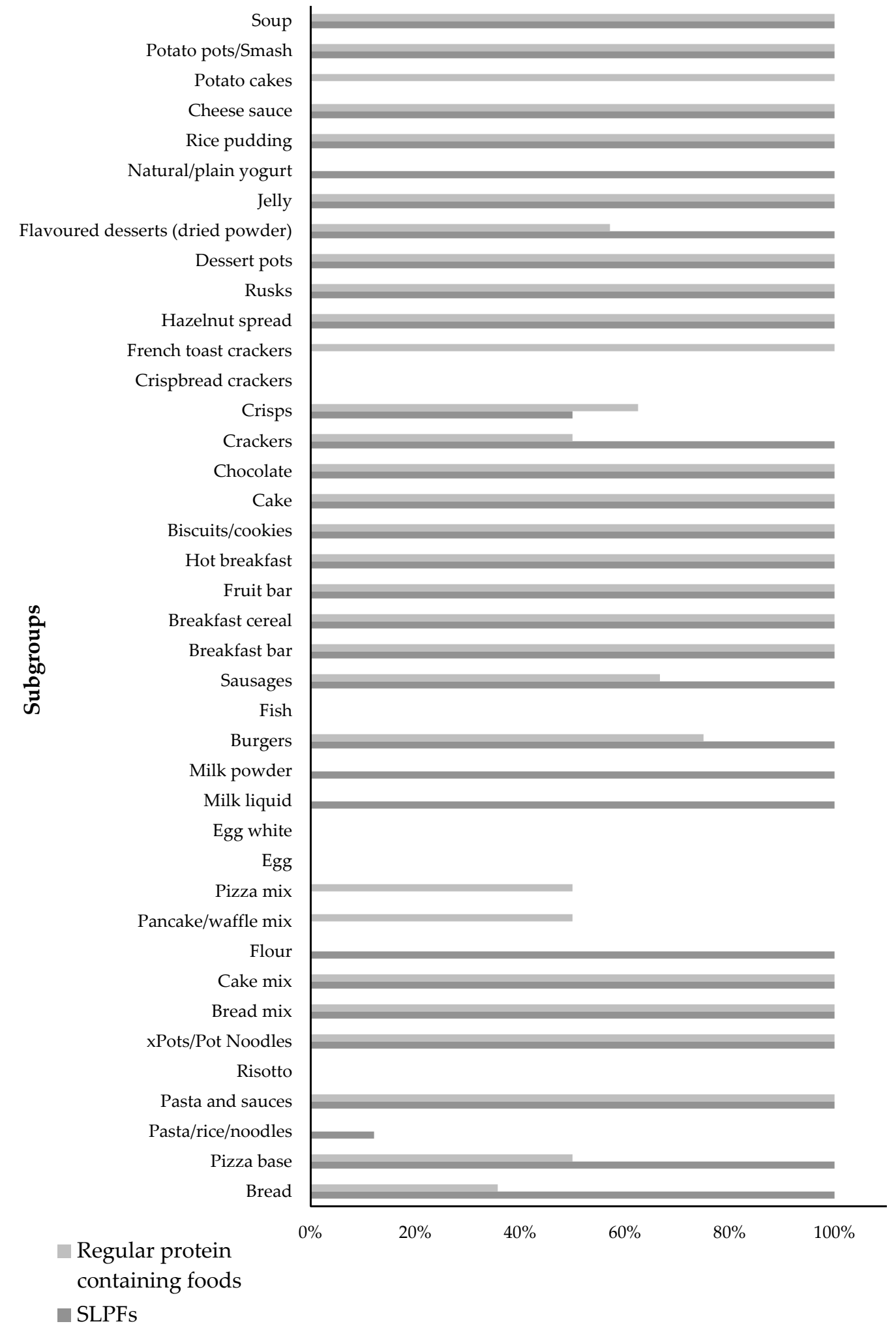

\section{$\%$ of products}

Figure 1. Percentage of regular and special low protein food (SLPF) products containing added sugar in their ingredient list by subgroup. 


\subsection{Total and Saturated Fat}

Sixty three percent $(n=25 / 40)$ of SLPF subgroups contained less total fat (including egg substitutes, meat replacements, flour/mixes, flavoured desserts (dried powder), dried breakfast cereal, pasta, rice and noodles), whilst 28\% ( $n=11 / 40)$ contained $21-94 \%$ more total fat (including breads, pizza bases, breakfast bars, fruit bars, chocolate, pasta and sauces, risotto, dessert pots, rusks and liquid milk replacers) than regular foods. In $8 \%(n=3 / 40)$ of the SLPF subgroups, total fat content was comparable to that found in regular foods. Calculation of percentage differences between SLPF egg whites and regular egg whites was not possible, due to SLPF egg whites reporting "nil added" for total fat content.

Thirty-five percent $(n=14 / 40)$ of SLPF subgroups contained more saturated fat (14-262\%) than regular foods, including cakes, breakfast bars, pizza bases, fruit bars, bread and breakfast cereals. Conversely, $50 \%(n=20 / 40)$ of SLPF subgroups contained less saturated fat $(<-10 \%)$ than regular foods. SLPF pizza mixes, cake mixes, eggs and fish substitutes contained $85-100 \%$ less saturated fat.

Palm oil was the most common fat source found in $25 \%(n=36 / 146)$ of SLPFs. Twenty-five (17\%) of these SLPFs did not specify if palm oil was hydrogenated or non-hydrogenated but one food contained partially hydrogenated palm oil $(<1 \%)$, one hydrogenated palm oil $(<1 \%)$ and nine non-hydrogenated palm oil (6\%) (Figure 2). Hydrogenated vegetable oil was another common fat source in SLPFs $(23 \%$, $n=33 / 146$ ) (Figure 2). SLPFs with "hydrogenated vegetable oil" or "hydrogenated palm oil" were all produced by the same manufacturer and it was unclear if the sources were partially hydrogenated. The most prevalent fat sources in regular foods were milk $(41 \%, n=78 / 190)$ and palm oil $(39 \%$, $n=75 / 190$ ), with no products listing hydrogenated oil sources (Figure 2). Palm oil was found in $80 \%$ $(n=20 / 25)$ of SLPF snacks compared with $58 \%(n=23 / 40)$ of regular snacks.

In the SLPF subgroups containing less saturated fat $(n=20 / 40)$, hydrogenated vegetable oil was present in $35 \%(n=7 / 20)$ (cheese sauce, soups, flavoured desserts, pasta and sauces, xPots and meat replacements).

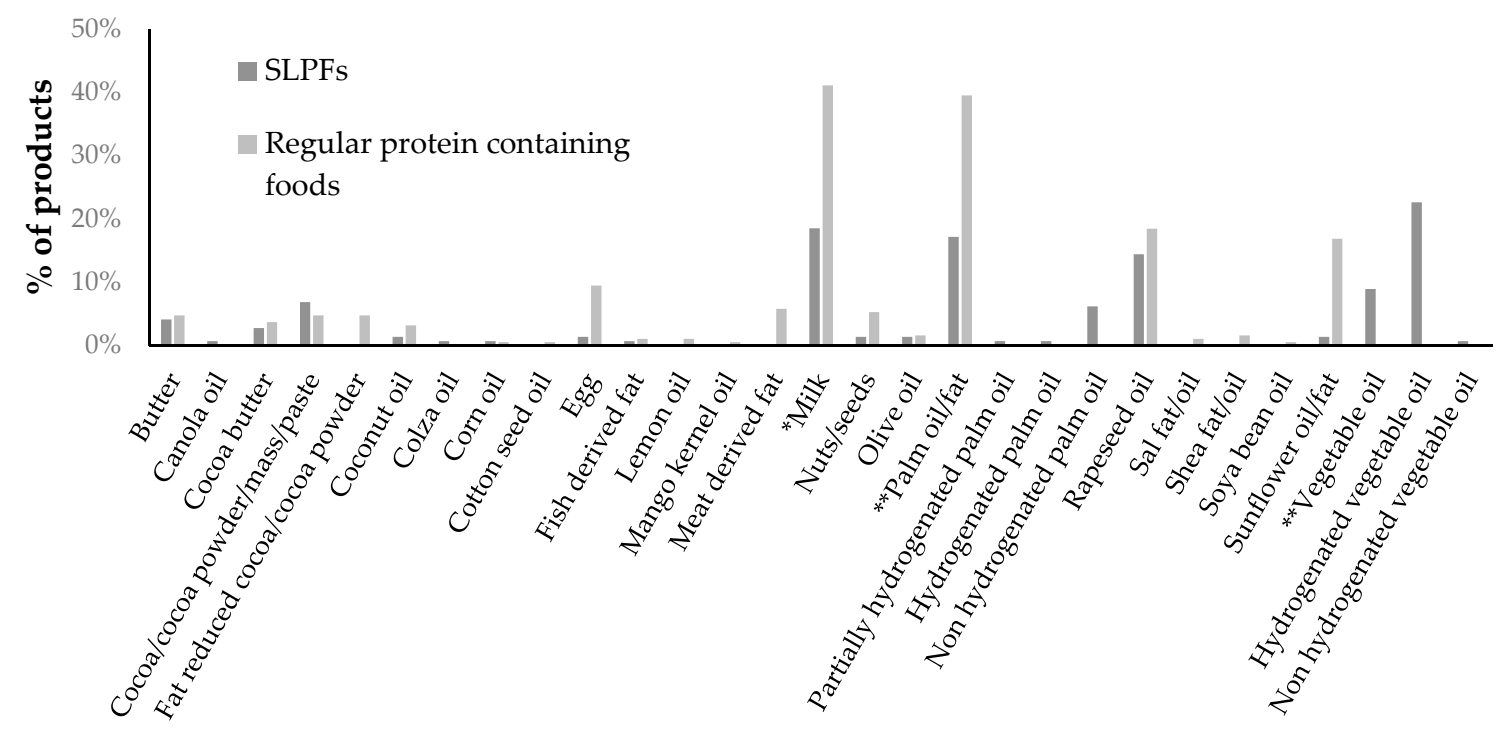

Type of fat

Figure 2. Percentage of SLPFs and regular protein containing foods containing different types of fat in their ingredient lists. ${ }^{*}$ Not including milk protein (where products specified this as an ingredient) ** oil/fat, did not specify whether it was hydrogenated or non-hydrogenated. 


\subsection{Fibre}

From the nutritional analysis, only $44 \%(n=64 / 146)$ of SLPFs quantified a fibre amount compared with $82 \%$ ( $n=156 / 190)$ of regular foods. When fibre content was listed, low protein milk (liquid) and egg substitutes contained more fibre than regular comparator foods which did not contain added fibre. Low protein French toast, chocolate, bread, pizza bases, cake mixes and fruit bars contained more fibre (16-189\%) than regular foods. The largest differences were for egg white replacers, burger and fish substitutes (1645-5050\%), with SLPFs containing higher amounts.

Some products contained natural fibre sources such as whole-wheat flour or apple flakes but only added fibre sources (e.g., barley/wheat/gluten-free wheat fibre, methylcellulose, pectin, guar gum etc.) were identified from the ingredient lists. Added fibre was found in $77 \%(n=113 / 146)$ of SLPFs but only $18 \%(n=34 / 190)$ of regular foods (Figure 3). The main fibre sources added to SLPFs were methylcellulose, guar gum, hydroxypropyl-methylcellulose, inulin and carob/locust bean gum. These were added to primarily improve texture and quality.

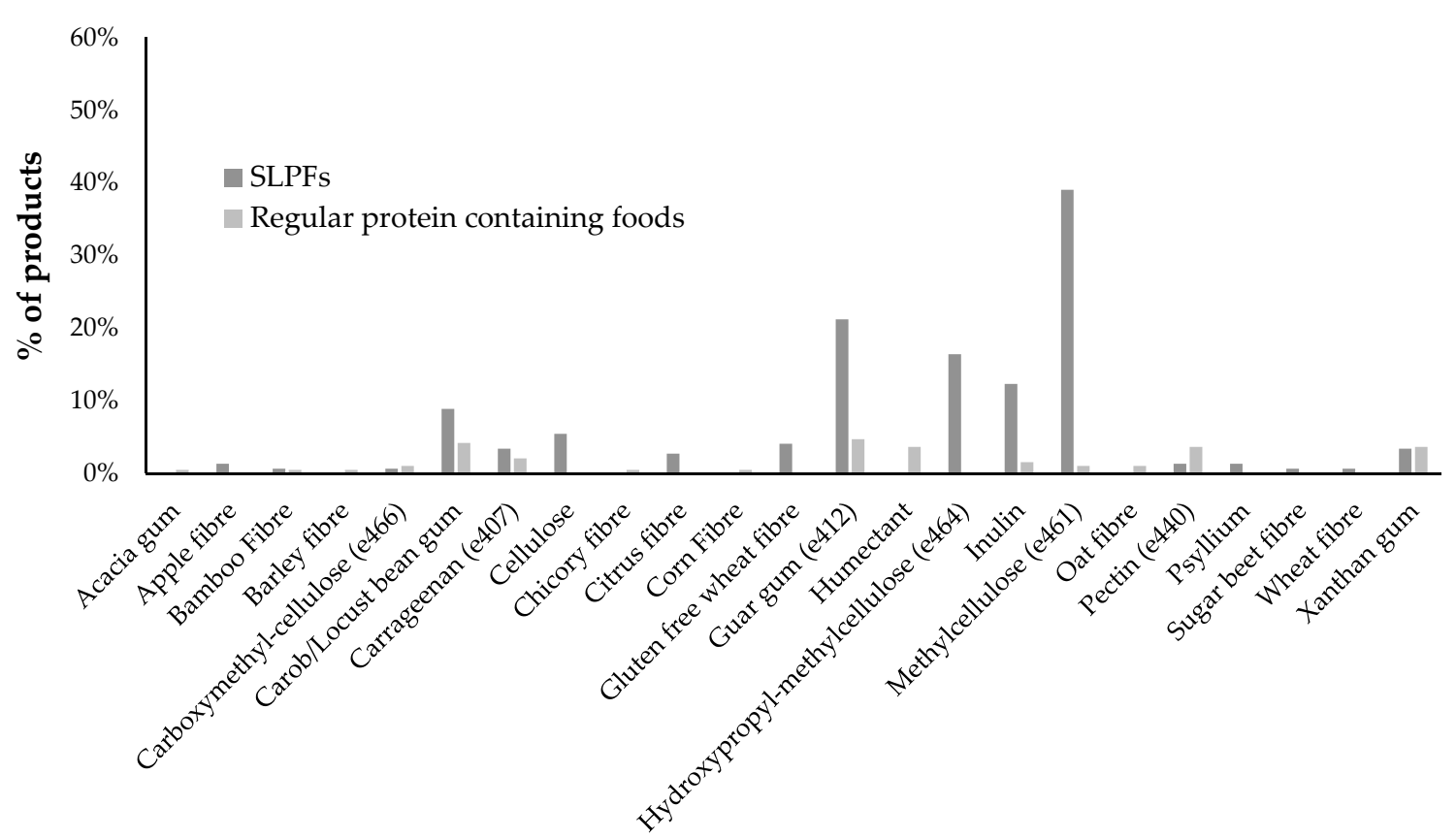

Type of added fibre

Figure 3. Percentage of regular and SLPF products containing added fibre in their ingredient lists by type of fibre.

\subsection{Salt}

Over $50 \%$ of SLPF subgroups contained $17-100 \%$ less salt than regular foods $(n=21 / 40)$, with low protein rice pudding, chocolate and jelly subgroups all containing $100 \%$ less. Salt content was higher in $33 \%$ of SLPF subgroups when compared to regular foods with higher amounts in low protein potato pots, xPots, hazelnut spread, crisps, cakes, hot breakfast cereal, fish substitute and pizza mix (100-1050\%).

\section{Discussion}

This is the first study to investigate the nutritional composition of all SLPFs available on UK ACBS prescription, compared with regular protein-containing foods, examining macronutrients and their ingredient sources. The overall nutrient quality of SLPFs was variable with no consistent pattern. Some of the nutrients reported on food labelling were incomplete with $56 \%$ of foods not itemising fibre content. The energy content of $50 \%$ of SLPF subgroups was comparable to regular foods, with only $23 \%$ of SLPF subgroups containing a higher amount $(>10 \%)$ than regular foods. 
Sixty three percent of SLPF subgroups contain less total fat and 50\% contain less saturated fat $(<-10 \%)$ when compared to regular foods, including: milk powder, eggs, biscuits/cookies, crisps, crispbread crackers, flavoured desserts, yogurt, cheese sauce, soup, potato cakes, meat and certain flour/mixes subgroups. This appears advantageous. Some studies in PKU, have reported improved or similar biomarkers of cardiovascular disease when compared to healthy controls [13-17]. However, although $50 \%$ of SLPF subgroups contained less saturated fat than regular foods, some of the subgroups listed hydrogenated vegetable oil as a fat source and did not specify if this was "partially" or "fully" hydrogenated. Full hydrogenation of vegetable oil produces exclusively saturated fats, whereas partial hydrogenation of vegetable oil leads to a higher amount of trans fatty acids [18,19]. Consumption of trans fatty acids has been linked to the development of several health problems, including metabolic syndrome, coronary heart disease, obesity and diabetes [18-20]. Although dietary trans fatty acids may have a similar elevating effect on LDL-cholesterol to that of saturated fatty acids, the former will contribute to HDL-cholesterol reduction [21]. Low HDL-cholesterol has already been reported in PKU patients [14]. Therefore, some SLPFs that may appear "healthier" with a low saturated fat content may actually be higher in trans fats, but this information is not disclosed by the manufacturers. In contrast, $35 \%$ of SLPF subgroups contained more saturated fat than regular foods, particularly staple items such as breakfast cereal and breads, which is a concern. Common fat sources were palm oil and hydrogenated vegetable oil, both of which contain saturated fat $[18,20,22,23]$. The chain length of saturated fat is important, with longer-chain saturated fatty acids being more harmful, whilst shortand medium-chain fatty acids have potential benefits on metabolic risk, weight gain, obesity and gut microbiome [24]. In summary, more precise information on the type of fat added is required for SLPFs.

Over $70 \%$ of SLPFs on UK prescription contained added sugar but this percentage was only slightly higher than regular foods. When subgroups were examined more closely, it was apparent that certain SLPFs commonly added sugar when regular foods did not. Specifically, $100 \%$ of low-protein breads, pizza bases, flour, meats, crackers, flavoured desserts, yogurt, milks and some pastas contained added sugar. Maize/corn and potato starch were the most frequently used starch sources in SLPFs with most ingredient lists indicating that these starches were present in isolation. Isolated starches are more refined than regular flour and/or raw materials, and foods containing isolated starches may have a higher glycaemic index (GI) than those made from wheat flour $[25,26]$. In contrast, the addition of fat to a regular carbohydrate food is known to delay gastric emptying and lower GI [27]. The GI of SLPFs available on UK ACBS prescription has not been formally evaluated. This needs to be determined as it is uncertain how the isolated starches, added sugar and increased levels of fat found in some SLPFs impact on GI function.

In PKU, a high carbohydrate intake and the carbohydrate profile of SLPFs may contribute to higher levels of insulin resistance, as a relationship between the quality and amount of carbohydrate in SLPFs and peripheral insulin resistance has been reported [11,28]. An association between the overall glycaemic load and triglyceride glucose index in children with PKU has also been described [11]. In patients with increased abdominal obesity (waist circumference), which is a component of metabolic syndrome, increased triglycerides, lower HDL-cholesterol and increased HOMA-IR (homeostasis model assessment of insulin resistance) is documented [14]. Insulin resistance, a marker of metabolic syndrome, is linked to an increased risk of cardiovascular disease [29].

Gluten and other proteins in regular grains/cereals are important in maintaining structural integrity, texture and quality of regular foods [25]. However, with the majority of SLPFs based on maize/corn/potato starches, it is not surprising that $77 \%$ of SLPFs contained added fibre, predominantly in the form of hydrocolloids. Hydrocolloids are additives that improve the quality, formulation and texture of low protein and gluten-free products $[25,26,30]$. Their contribution as a source of dietary fibre has not been explored, despite the fibre content of hydrocolloids typically varying between $60-90 \%$ [31]. Generally, such additives are used in small amounts and are commonly not significant enough to make a fibre claim on a product [31]. However, in patients with PKU where approximately $50 \%$ of their energy intake may be from SLPFs [3] containing hydrocolloids, it is probable that these ingredients are 
significantly contributing to daily fibre intake, although this remains unreported. Therefore, regular consumption of SLPFs may also have an impact on gastrointestinal function and gut microbiome, with previous research reporting that $34 \%$ of patients with PKU suffer from digestive problems [2].

Over 30\% of SLPF subgroups contained more salt than regular foods, with some containing 100-1050\% extra. It is possible that their habitual consumption may contribute to nutritional co-morbidities such as hypertension [32-34], vascular stiffness [34,35], overweight/obesity [3,34,36-40] and an atherogenic lipoprotein profile [34].

For $91 \%$ of SLPFs, phenylalanine content was $\leq 25 \mathrm{mg} / 100 \mathrm{~g}$ of the product, or all product ingredients were "exchange-free", meaning these items can be eaten without measurement [41]. The remaining 9\% of SLPFs contained phenylalanine $>25 \mathrm{mg} / 100 \mathrm{~g}$ and included ingredients such as milk and potato flakes; and consequently, these foods must be restricted and given in controlled amounts in a low phenylalanine diet [41]. The few SLPFs containing $>25 \mathrm{mg} / 100 \mathrm{~g}$ add complexity to a low phenylalanine diet as patients and caregivers may be unsure about their suitability.

Overall, there is limited research into the dietary patterns of patients with PKU, but evidence suggests that SLPFs contribute up to $47 \%$ of energy intake [11]. Many contemporary low phenylalanine protein substitutes have a low fat and carbohydrate content, meaning there is an increased reliance on SLPFs to provide these macronutrients [42,43]. With a "treatment for life" policy, it is essential that SLPFs have a nutritional profile that supports long term healthy eating patterns.

There are many recommendations required to improve standards in the nutritional composition and labelling of UK SLPFs. Transparency is necessary by SLPF manufacturers about the nutritional profile of their products. All ingredients should be clearly listed including sources of, at least, starch, sugar, fat and fibre and the amount of fibre added (per $100 \mathrm{~g} / 100 \mathrm{~mL}$ ) for all SLPFs. Nutritional analysis for both dried and prepared weights should be available. Packaging and website nutritional information should be accurate and consistent. To ensure that all SLPFs can be safely consumed without calculation and measurement, the phenylalanine content should be no more than $25 \mathrm{mg} / 100 \mathrm{~g}$ for all prescribed SLPFs; and no more phenylalanine than $5 \mathrm{mg} / 100 \mathrm{~mL}$ for milk replacements [44]. SLPF macronutrient composition regulations should be strengthened, ensuring similarity to regular protein-containing comparators. Upper limits should be set for carbohydrate and fat content. Fat sources should be predominantly poly- or mono-unsaturated rather than saturated or trans-fats; the addition of trans fatty acid sources should be clearly labelled. Fortunately, the EU Commission, 2019, has now adopted a regulation setting a maximum limit for trans-fats in industrially produced trans-fat of $2 \mathrm{~g} / 100 \mathrm{~g}$ of fat [45]. Some isolated starches could be replaced by plants naturally low in phenylalanine such as cassava. In SLPFs, added sugar should be restricted if protein-containing comparators do not contain it. It is hypothesised that high sugar consumption may affect gut microbiota, disturbing the crosstalk between the gut and systemic metabolism, with a potentially harmful impact on metabolic health [46]. Reducing the salt content of some savoury products and replacing it with herbs and spices to improve or maintain the taste and flavour of SLPFs would be beneficial. A simple traffic light colour system has been proposed to categorise SLPFs based on their nutritional profile [10] and this may help patients reduce refined carbohydrate and salt intake and increase their consumption of healthier fats and complex carbohydrates.

In this evaluation of SLPFs, difficulties in accessing nutritional composition data has led to several limitations. Data was missing for some key nutrients such as fibre. Nutritional values were often reported as " $<0.5$ " or " $<0.1$ ", and so the precise content was unclear. There were occasional discrepancies in nutritional information between SLPFs and regular foods. Some foods provided information for dried ingredients whilst others only for cooked/prepared products. The selection of protein-containing foods as comparators and how the products were grouped was subjective. Finally, this study only examined products accessible on UK prescription compared with protein-containing products available from UK supermarkets. Detailed nutritional composition analysis of SLPFs available on prescription compared with regular equivalent products in other countries is warranted to determine if findings are consistent. 


\section{Conclusions}

In conclusion, this UK study shows that the nutritional content of SLPFs available on ACBS prescription differed to regular comparable foods but with no clear consistent pattern. Almost two thirds of SLPF subgroups contained less total fat but with palm oil and hydrogenated vegetable oil as key fat sources. Over two thirds of SLPF subgroups contained more carbohydrate commonly as isolated starches. More added fibre was identified in SLPFs but predominantly in the form of hydrocolloids. It is possible that habitual consumption of SLPFs higher in salt, sugars, isolated starches, or saturated fat may contribute to future nutritional comorbidities.

Stricter nutritional composition regulations, improvements in product labelling and access to full nutritional composition data will allow health professionals and patients to make informed decisions when prescribing and using SLPFs. Identifying upper limits for macronutrients, and improving fat and carbohydrate sources is essential in supporting patients with PKU in meeting their nutritional needs and improving health outcomes.

Author Contributions: Conceptualization, S.E. and A.M.; Data curation, G.W.; Formal analysis, G.W.; Investigation, G.W.; Methodology, G.W., S.E. and A.M.; Supervision, S.E., K.P.-B. and A.M.; Visualization, G.W., S.E., K.P.-B., J.C.R. and A.M.; Writing—original draft, G.W.; Writing—review and editing, G.E., S.E., K.P.-B., J.C.R. and A.M. All authors have read and agree to the published version of the manuscript.

Funding: This research received no external funding.

Acknowledgments: Thank you to the suppliers/manufacturers of special low protein foods for providing nutritional composition data for your products.

Conflicts of Interest: A.M. has been a member of the European Nutritionist Expert Panel Biomarin, Sapropterin Advisory Board Biomarin, the advisory board ELEMENT Danone-Nutricia, the advisory board for Arla and Applied Pharma Research, and received research funding and honoraria from Nutricia, Vitaflo International and Merck Serono. J.C.R. has been a member of the European Nutritionist Expert Panel (Biomarin), the Advisory Board for Applied Pharma Research and Nutricia, and received honoraria as a speaker from APR, Merck Serono, Biomarin, Nutricia, Vitaflo, Cambrooke, PIAM and Lifediet. S.E. receives research funding from Nutricia, and has received financial support and honoraria from Nutricia and Vitaflo to attend/speak at study days and conferences. 


\section{Appendix A}

Table A1. Nutritional composition data for all low protein and regular subgroups analysed per $100 \mathrm{~g}$ of product. Values displayed as Mean (range).

\begin{tabular}{|c|c|c|c|c|c|c|c|c|c|c|}
\hline \multicolumn{2}{|c|}{ Product } & $\begin{array}{l}\text { Energy (kcal) } \\
\text { per } 100 \mathrm{~g}\end{array}$ & $\begin{array}{c}\text { Protein }(\mathrm{g}) \\
\text { per } 100 \mathrm{~g}\end{array}$ & $\begin{array}{l}\text { Phenylalanine } \\
\text { (mg) per } 100 \mathrm{~g}\end{array}$ & $\begin{array}{l}\quad \text { Total } \\
\text { Carbohydrate } \\
\text { (g) per } 100 \mathrm{~g}\end{array}$ & $\begin{array}{l}\text { Carbohydrate of } \\
\text { Which Is Sugars (g) } \\
\text { per } 100 \mathrm{~g} \text { per } 100 \mathrm{~g}\end{array}$ & $\begin{array}{l}\text { Fibre }(\mathrm{g}) \text { per } \\
\quad 100 \mathrm{~g}\end{array}$ & $\begin{array}{l}\text { Total Fat (g) } \\
\text { per } 100 \mathrm{~g}\end{array}$ & $\begin{array}{l}\text { Saturated } \\
\text { Fat }(\mathrm{g}) \text { per } \\
100 \mathrm{~g}\end{array}$ & $\begin{array}{c}\text { Salt }(\mathrm{g}) \\
\text { per } 100 \mathrm{~g}\end{array}$ \\
\hline \multicolumn{11}{|c|}{ Breads/Pizza bases } \\
\hline \multirow{3}{*}{ Bread } & $\operatorname{SLPF}(n=13)$ & $\begin{array}{c}244 \\
(214-266)\end{array}$ & $\begin{array}{c}0.6 \\
(0.2-1.0)\end{array}$ & $\begin{array}{c}15 \\
(8-30)\end{array}$ & $\begin{array}{c}47.1 \\
(37.0-53.8)\end{array}$ & $\begin{array}{c}3 \\
(1.4-4.3)\end{array}$ & $\begin{array}{c}9.2 \\
(3.8-16.0)\end{array}$ & $\begin{array}{c}4.3 \\
(2.7-5.3)\end{array}$ & $\begin{array}{c}1.2 \\
(0.3-2.3)\end{array}$ & $\begin{array}{c}0.5 \\
(0.3-1.3)\end{array}$ \\
\hline & Regular $(n=14)$ & $\begin{array}{c}255 \\
(221-285)\end{array}$ & $\begin{array}{c}9.7 \\
(8.4-11.9)\end{array}$ & $\begin{array}{c}485 \\
(420-595)\end{array}$ & $\begin{array}{c}46.6 \\
(31.4-58.8)\end{array}$ & $\begin{array}{c}3.1 \\
(2.2-4.1)\end{array}$ & $\begin{array}{c}4 \\
(1.6-12.4)\end{array}$ & $\begin{array}{c}2.5 \\
(0.6-7.5)\end{array}$ & $\begin{array}{c}0.5 \\
(0.2-1.4)\end{array}$ & $\begin{array}{c}0.9 \\
(0.7-1.1)\end{array}$ \\
\hline & \% Difference & $-4 \%$ & $-94 \%$ & $-97 \%$ & $1 \%$ & $-3 \%$ & $130 \%$ & $72 \%$ & $140 \%$ & $-44 \%$ \\
\hline \multirow{3}{*}{ Pizza base } & $\operatorname{SLPF}(n=2)$ & $\begin{array}{c}290 \\
(263-316)\end{array}$ & $\begin{array}{c}0.9 \\
(0.8-0.9)\end{array}$ & $\begin{array}{c}13 \\
(2-24)\end{array}$ & $\begin{array}{c}55.7 \\
(49.0-62.3)\end{array}$ & $\begin{array}{c}4.9 \\
(4.7-5.0)\end{array}$ & $\begin{array}{c}7.8 \\
(2.6-13)\end{array}$ & $\begin{array}{c}5.4 \\
(4.2-6.5)\end{array}$ & $\begin{array}{c}1.7 \\
(1.4-2.0)\end{array}$ & $\begin{array}{c}0.5 \\
(0.3-0.8)\end{array}$ \\
\hline & $\operatorname{Regular}(n=2)$ & 296 & $\begin{array}{c}8.9 \\
(8.90)\end{array}$ & 445 & 54.3 & 2.4 & 2.7 & 4.2 & 0.6 & 1.4 \\
\hline & \% Difference & $\begin{array}{c}(200-504) \\
-2 \%\end{array}$ & $\begin{array}{l}(0.0-9.0) \\
-90 \%\end{array}$ & $\begin{array}{l}(440-450) \\
-97 \%\end{array}$ & $\begin{array}{l}(51.6-5 / .0) \\
3 \%\end{array}$ & $\begin{array}{l}(2.4-2.4) \\
104 \%\end{array}$ & $\begin{array}{l}(2.6-2.8) \\
189 \%\end{array}$ & $\begin{array}{c}(2.1-6.3) \\
29 \%\end{array}$ & $\begin{array}{l}(0.0-0.9) \\
183 \%\end{array}$ & $\begin{array}{l}(1.4-1.4) \\
-64 \%\end{array}$ \\
\hline \multicolumn{11}{|c|}{ Pasta/rice/noodles } \\
\hline \multirow{3}{*}{ Pasta/rice/noodles } & $\operatorname{SLPF}(n=33)$ & $\begin{array}{c}356 \\
(343-366)\end{array}$ & $\begin{array}{c}0.3 \\
(0.1-0.5)\end{array}$ & $\begin{array}{c}13 \\
(8-25)\end{array}$ & $\begin{array}{c}85.8 \\
(79.0-88.1)\end{array}$ & $\begin{array}{c}0.6 \\
(0.0-3.2)\end{array}$ & $\begin{array}{c}3.1 \\
(0.2-7.3)\end{array}$ & $\begin{array}{c}0.9 \\
(0.6-1.6)\end{array}$ & $\begin{array}{c}0.5 \\
(0.2-0.9)\end{array}$ & $\begin{array}{c}0.1 \\
(0.1-0.5)\end{array}$ \\
\hline & Regular $(n=23)$ & 356 & 11.9 & 595 & 72.5 & 2.4 & 2.9 & 1.8 & 0.4 & 0.1 \\
\hline & \% Difference & $\begin{array}{c}(336-380) \\
0 \%\end{array}$ & $(7.2-14.0)$ & $(360-700)$ & $(68.6-78.1)$ & $(0.0-4.8)$ & $(1.0-4.3)$ & $(0.7-3.3)$ & $(0.2-0.9)$ & $(0.0-0.8)$ \\
\hline \multirow{5}{*}{ Pasta and sauce } & о & $0 \%$ & $-97 \%$ & $-98 \%$ & $18 \%$ & $-75 \%$ & $7 \%$ & $-50 \%$ & $25 \%$ & \\
\hline & $\operatorname{SLPF}(n=5)$ & $\begin{array}{c}123 \\
(98-140)\end{array}$ & $\begin{array}{c}0.5 \\
(0.3-0.6)\end{array}$ & $\begin{array}{c}8 \\
(3-14)\end{array}$ & $\begin{array}{c}25.9 \\
(23.9-31.3)\end{array}$ & $\begin{array}{c}1.9 \\
(0.4-4.9)\end{array}$ & No values & $\begin{array}{c}2 \\
(0.1-1.1)\end{array}$ & $\begin{array}{c}0.6 \\
(0.0-1.1)\end{array}$ & $\begin{array}{c}0.8 \\
(0.6-1.0)\end{array}$ \\
\hline & Regular $(n=10)$ & 104 & 3.5 & 175 & 18.1 & 2.5 & 1.2 & 1.6 & 0.8 & 0.6 \\
\hline & 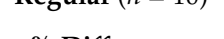 & (81-137) & $(2.7-4.8)$ & $(135-240)$ & $(14.0-25.1)$ & $(0.8-4.6)$ & $(<0.5-2.1)$ & $(0.6-4.1)$ & $(0.1-2.4)$ & $(0.3-0.8)$ \\
\hline & \% Difference & $18 \%$ & $-86 \%$ & $-95 \%$ & $43 \%$ & $-24 \%$ & - & $25 \%$ & $-25 \%$ & $33 \%$ \\
\hline \multirow{4}{*}{ Risotto } & $\operatorname{SLPF}(n=1)$ & 103 & 0.3 & 6 & 14 & $<0.2$ & 0.5 & 5 & 1.3 & 0.7 \\
\hline & Regular $(n=2)$ & 95 & 2.9 & 145 & 13.8 & 1.4 & 1.4 & 3 & 1.1 & 0.5 \\
\hline & & (93-97) & $(2.3-3.4)$ & (115-170) & $(13.6-14.0)$ & $(1.0-1.7)$ & (1 value) & $(2.3-3.6)$ & $(1.1-1.1)$ & $(0.4-0.5)$ \\
\hline & \% Difference & $8 \%$ & $-90 \%$ & $-96 \%$ & $1 \%$ & $-86 \%$ & $-64 \%$ & $67 \%$ & $18 \%$ & $40 \%$ \\
\hline \multirow{4}{*}{ xPots/pot noodles } & $\operatorname{SLPF}(n=4)$ & $\begin{array}{c}138 \\
(136-140)\end{array}$ & $\begin{array}{c}0.4 \\
(0.3-0.6)\end{array}$ & $\begin{array}{c}9 \\
(6-15)\end{array}$ & $\begin{array}{c}23 \\
(22.6-23.5)\end{array}$ & $\begin{array}{c}1.8 \\
(1.6-2.1)\end{array}$ & No values & $\begin{array}{c}4.8 \\
(4.5-5.1)\end{array}$ & $\begin{array}{c}0.9 \\
(0.7-1.1)\end{array}$ & $\begin{array}{c}1.9 \\
(1.6-2.3)\end{array}$ \\
\hline & $\operatorname{Regular}(n=8)$ & 131 & 2.9 & 145 & 19.1 & 1.5 & 1.1 & 4.5 & 1.9 & 0.5 \\
\hline & $\operatorname{Regular}(n=8)$ & $(83-145)$ & $(2.3-3.5)$ & $(115-175)$ & $(17.4-21.6)$ & $(0.9-2.3)$ & $(0.8-1.3)$ & $(0.3-5.7)$ & $(<0.1-2.9)$ & $(0.4-0.7)$ \\
\hline & \% Difference & $5 \%$ & $-86 \%$ & $-94 \%$ & $20 \%$ & $20 \%$ & - & $7 \%$ & $-54 \%$ & $280 \%$ \\
\hline
\end{tabular}


Table A1. Cont.

\begin{tabular}{|c|c|c|c|c|c|c|c|c|c|c|}
\hline \multicolumn{2}{|c|}{ Product } & $\begin{array}{l}\text { Energy (kcal) } \\
\text { per } 100 \mathrm{~g}\end{array}$ & $\begin{array}{l}\text { Protein }(\mathrm{g}) \\
\text { per } 100 \mathrm{~g}\end{array}$ & $\begin{array}{l}\text { Phenylalanine } \\
\text { (mg) per } 100 \mathrm{~g}\end{array}$ & $\begin{array}{l}\quad \text { Total } \\
\text { Carbohydrate } \\
\text { (g) per } 100 \mathrm{~g}\end{array}$ & $\begin{array}{l}\text { Carbohydrate of } \\
\text { Which Is Sugars }(\mathrm{g}) \\
\text { per } 100 \mathrm{~g} \text { per } 100 \mathrm{~g}\end{array}$ & $\begin{array}{l}\text { Fibre }(\mathrm{g}) \text { per } \\
\quad 100 \mathrm{~g}\end{array}$ & $\begin{array}{c}\text { Total Fat }(\mathrm{g}) \\
\text { per } 100 \mathrm{~g}\end{array}$ & $\begin{array}{l}\text { Saturated } \\
\text { Fat }(\mathrm{g}) \text { per } \\
100 \mathrm{~g}\end{array}$ & $\begin{array}{c}\text { Salt }(\mathrm{g}) \\
\text { per } 100 \mathrm{~g}\end{array}$ \\
\hline \multicolumn{11}{|c|}{ Flour/mixes } \\
\hline \multirow{3}{*}{ Bread mix } & $\operatorname{SLPF}(n=3)$ & $\begin{array}{c}347 \\
(339-354)\end{array}$ & $\begin{array}{c}0.4 \\
(0.1-0.7)\end{array}$ & $\begin{array}{c}15 \\
(4-20)\end{array}$ & $\begin{array}{c}83 \\
(80.1-86.0)\end{array}$ & $\begin{array}{c}2.8 \\
(1.7-4.6)\end{array}$ & $\begin{array}{c}2.5 \\
(2.0-3.0)\end{array}$ & $\begin{array}{c}0.6 \\
(0.5-0.7)\end{array}$ & $\begin{array}{c}0.3 \\
(0.1-0.5)\end{array}$ & $\begin{array}{c}0.4 \\
(0.1-0.6)\end{array}$ \\
\hline & Regular $(n=2)$ & $\begin{array}{c}338 \\
(334-341)\end{array}$ & $\begin{array}{c}13.1 \\
(13.0-13.1)\end{array}$ & $\begin{array}{c}655 \\
(650-655)\end{array}$ & $\begin{array}{c}70.4 \\
(67.6-73.1)\end{array}$ & $\begin{array}{c}3.1 \\
(1.8-4.4)\end{array}$ & $\begin{array}{c}3.1 \\
(2.8-3.4)\end{array}$ & $\begin{array}{c}1.6 \\
(1.2-2.0)\end{array}$ & $\begin{array}{c}0.3 \\
(0.3-0.3)\end{array}$ & $\begin{array}{c}1.6 \\
(1.3-1.9)\end{array}$ \\
\hline & \% Difference & $3 \%$ & $-97 \%$ & $-98 \%$ & $18 \%$ & $-10 \%$ & $-19 \%$ & $-63 \%$ & $0 \%$ & $-75 \%$ \\
\hline \multirow{4}{*}{ Cake mix } & $\operatorname{SLPF}(n=4)$ & $\begin{array}{c}366 \\
(365-367)\end{array}$ & $\begin{array}{c}0.5 \\
(0.2-0.9)\end{array}$ & $\begin{array}{c}14 \\
(4-30)\end{array}$ & $\begin{array}{c}89 \\
(84.6-92.1)\end{array}$ & $\begin{array}{c}39.6 \\
(35.7-47.9)\end{array}$ & $\begin{array}{c}3.4 \\
(1.8-7.1)\end{array}$ & $\begin{array}{c}0.7 \\
(0.1-1.3)\end{array}$ & $\begin{array}{c}0.4 \\
(0.0-0.9)\end{array}$ & $\begin{array}{c}0.8 \\
(0.6-0.8)\end{array}$ \\
\hline & $\operatorname{Regular}(n=4)$ & 381 & 5.8 & 290 & 77.4 & 43.5 & 2.1 & 5 & 2.7 & 1.5 \\
\hline & Kegurar $(n=4)$ & $(370-395)$ & $(4.6-6.9)$ & $(230-345)$ & (74.7-81.9) & $(32.8-47.6)$ & $(1.1-3.4)$ & $(4.7-5.3)$ & $(2.5-2.9)$ & $(1.2-2.1)$ \\
\hline & $\%$ Difference & $-4 \%$ & $-91 \%$ & $-95 \%$ & $15 \%$ & $-9 \%$ & $62 \%$ & $-86 \%$ & $-85 \%$ & $-47 \%$ \\
\hline \multirow{4}{*}{ Flour } & $\operatorname{SLPF}(n=4)$ & $\begin{array}{c}349 \\
(339-361)\end{array}$ & $\begin{array}{c}0.2 \\
(0.1-0.3)\end{array}$ & $\begin{array}{c}5 \\
(4-<10)\end{array}$ & $\begin{array}{c}85.3 \\
(80.1-88.3)\end{array}$ & $\begin{array}{c}5.6 \\
(4.6-7.2)\end{array}$ & $\begin{array}{c}2.6 \\
(2.1-3.1)\end{array}$ & $\begin{array}{c}0.3 \\
(0.0-0.5)\end{array}$ & $\begin{array}{c}0.1 \\
(0.1-0.2)\end{array}$ & $\begin{array}{c}0.6 \\
(0.4-0.7)\end{array}$ \\
\hline & & 335 & 9.8 & 490 & 70 & 1.5 & & 1.1 & 0.2 & 0.9 \\
\hline & $\operatorname{Regular}(n=2)$ & $(330-340)$ & $(9.6-9.9)$ & $(480-495)$ & $(67.9-72.0)$ & $(1.3-1.7)$ & No values & $(0.7-1.4)$ & $(0.1-0.2)$ & $(0.8-1.1)$ \\
\hline & \% Difference & $4 \%$ & $-98 \%$ & $-99 \%$ & $22 \%$ & $273 \%$ & - & $-73 \%$ & $-50 \%$ & $-33 \%$ \\
\hline \multirow{4}{*}{$\begin{array}{c}\text { Pancake/waffle } \\
\text { mix }\end{array}$} & $\operatorname{SLPF}(n=1)$ & 353 & 0.5 & 22 & 86.5 & 14 & 0.6 & 0.4 & $<0.1$ & 0.2 \\
\hline & & 434 & 9.3 & 465 & 72.1 & 9.6 & 2.6 & 1.3 & 0.2 & 3.1 \\
\hline & $\operatorname{Regular}(n=2)$ & $(335-532)$ & $(8.5-10.0)$ & $(425-500)$ & $(70.2-74.0)$ & $(4.2-14.9)$ & $(2.6-2.6)$ & $(1.1-1.4)$ & $(0.0-0.3)$ & $(2.3-3.8)$ \\
\hline & \% Difference & $-19 \%$ & $-95 \%$ & $-95 \%$ & $20 \%$ & $46 \%$ & $-77 \%$ & $-69 \%$ & $-51 \%$ & $-94 \%$ \\
\hline \multirow{4}{*}{$\begin{array}{l}\text { Pizza mix (dried } \\
\text { powder) }\end{array}$} & $\operatorname{SLPF}(n=1)$ & 353 & 0.2 & $<31$ & 86.9 & $<0.1$ & No value & $<0.5$ & $<0.1$ & 1.4 \\
\hline & $\operatorname{Regular}(n=2)$ & 379 & 12.1 & 605 & 70 & 3.9 & 4.3 & 4.7 & 1.7 & 0.4 \\
\hline & Negurar $(n-2)$ & $(372-386)$ & $(11.3-13.0)$ & $(565-650)$ & $(69.4-70.6)$ & $(3.9-3.9)$ & $(4.0-4.6)$ & $(4.4-4.9)$ & $(1.5-1.9)$ & $(0.4-0.4)$ \\
\hline & \% Difference & $-7 \%$ & $-98 \%$ & $-95 \%$ & $24 \%$ & $-97 \%$ & - & $-89 \%$ & $-94 \%$ & $250 \%$ \\
\hline \multicolumn{11}{|c|}{ Eggs/replacers } \\
\hline \multirow{5}{*}{ Egg } & $\operatorname{SLPF}(n=3)$ & 44 & 0 & 1 & 10.7 & 0 & 0.5 & 0 & 0 & 0.1 \\
\hline & (prepared) & $(32-68)$ & $(0.0-0.0)$ & $(1-1)$ & $(7.5-16.8)$ & $(0.0-0.0)$ & $(0.3-0.7)$ & $(0.0-0.0)$ & $(0.0-0.0)$ & $(0.0-0.1)$ \\
\hline & $\operatorname{Regular}(n=2)$ & 131 & 12.6 & 630 & 0.2 & 0.2 & 0 & 9 & 2.5 & 0.4 \\
\hline & Neguiar $(n-2)$ & (131-131) & $(12.6-12.6)$ & $(630-630)$ & $(0.0-<0.5)$ & $(0.0-<0.5)$ & Only 1 value & $(9.0-9.0)$ & $(2.5-2.5)$ & $(0.4-0.4)$ \\
\hline & \% Difference & $-66 \%$ & $-100 \%$ & $-100 \%$ & $5250 \%$ & $-100 \%$ & - & $-100 \%$ & $-100 \%$ & $-75 \%$ \\
\hline \multirow{4}{*}{ Egg white } & $\operatorname{SLPF}(n=1)$ & 185 & Nil added & Nil added & Nil added & Nil added & 92.5 & Nil added & Nil added & 1 \\
\hline & $\operatorname{Regular}(n=2)$ & 354 & 83.3 & 4165 & 3.4 & 0.3 & 5.3 & 0.4 & 0.1 & 2.6 \\
\hline & Neguiar $(n-2)$ & $(345-363)$ & $(82.6-84.0)$ & (4130-4200) & $(<0.5-6.3)$ & $(0.0-<0.5)$ & Only 1 value & $(0.2-<0.5)$ & $(<0.1-0.1)$ & $(1.8-3.4)$ \\
\hline & \% Difference & $-48 \%$ & - & - & - & - & $1645 \%$ & - & - & $-62 \%$ \\
\hline
\end{tabular}


Table A1. Cont.

\begin{tabular}{|c|c|c|c|c|c|c|c|c|c|c|}
\hline \multicolumn{2}{|c|}{ Product } & $\begin{array}{c}\text { Energy (kcal) } \\
\text { per } 100 \mathrm{~g}\end{array}$ & $\begin{array}{l}\text { Protein }(\mathrm{g}) \\
\text { per } 100 \mathrm{~g}\end{array}$ & $\begin{array}{l}\text { Phenylalanine } \\
(\mathrm{mg}) \text { per } 100 \mathrm{~g}\end{array}$ & $\begin{array}{l}\text { Total } \\
\text { Carbohydrate } \\
\text { (g) per } 100 \mathrm{~g}\end{array}$ & $\begin{array}{l}\text { Carbohydrate of } \\
\text { Which Is Sugars }(\mathrm{g}) \\
\text { per } 100 \mathrm{~g} \text { per } 100 \mathrm{~g}\end{array}$ & $\begin{array}{l}\text { Fibre }(\mathrm{g}) \text { per } \\
\quad 100 \mathrm{~g}\end{array}$ & $\begin{array}{l}\text { Total Fat (g) } \\
\text { per } 100 \mathrm{~g}\end{array}$ & $\begin{array}{l}\text { Saturated } \\
\text { Fat }(\mathrm{g}) \text { per } \\
100 \mathrm{~g}\end{array}$ & $\begin{array}{c}\text { Salt (g) } \\
\text { per } 100 \mathrm{~g}\end{array}$ \\
\hline \multicolumn{11}{|c|}{ Milk/replacers } \\
\hline \multirow{3}{*}{ Milk (liquid) } & $\operatorname{SLPF}(n=4)$ & $\begin{array}{c}62 \\
(40-89)\end{array}$ & $\begin{array}{c}0.2 \\
(0.0-0.4)\end{array}$ & $\begin{array}{c}6 \\
(0-10)\end{array}$ & $\begin{array}{c}7.6 \\
(5.0-10.8)\end{array}$ & $\begin{array}{c}4.5 \\
(3.5-5.8)\end{array}$ & $\begin{array}{c}0.5 \\
(0.2-0.8)\end{array}$ & $\begin{array}{c}3.3 \\
(2.0-4.7)\end{array}$ & $\begin{array}{c}1.7 \\
(1.3-2.3)\end{array}$ & $\begin{array}{c}0.1 \\
(0.0-0.2)\end{array}$ \\
\hline & $\operatorname{Regular}(n=2)$ & 58 & 3.5 & 175 & 4.8 & 4.8 & $\begin{array}{c}0 \\
0\end{array}$ & 2.7 & 1.7 & 0.1 \\
\hline & \% Difference & $\begin{array}{c}(50-65) \\
7 \%\end{array}$ & $\begin{array}{c}(3.4-3.6) \\
-94 \%\end{array}$ & $\begin{array}{c}(1 / 0-180) \\
-97 \%\end{array}$ & $\begin{array}{c}(4.7-4.8) \\
58 \%\end{array}$ & $\begin{array}{c}(4.7-4.8) \\
-6 \%\end{array}$ & $\begin{array}{c}(0.0-0.0) \\
-\end{array}$ & $\begin{array}{c}(1.8-3.6) \\
22 \%\end{array}$ & $\begin{array}{c}(1.1-2.3) \\
0 \%\end{array}$ & $\begin{array}{c}(0.1-0.1) \\
0 \%\end{array}$ \\
\hline \multirow{4}{*}{ Milk (powder) } & $\operatorname{SLPF}(n=1)$ & 428 & 1.7 & 20 & 77.5 & 45.1 & No value & 12.3 & 6.2 & 0.7 \\
\hline & Reoular (n-?) & 428 & 30.8 & 1540 & 43.5 & 43.2 & 0.5 & 14.4 & 9 & 1 \\
\hline & $\operatorname{Regular}(n=2)$ & $(353-503)$ & $(25.7-35.9)$ & (1285-1795) & $(36.5-50.5)$ & $(36.5-49.8)$ & $(0.0-1.0)$ & $(0.6-28.2)$ & $(0.4-17.6)$ & $(0.9-1.1)$ \\
\hline & $\%$ Difference & $0 \%$ & $-94 \%$ & $-99 \%$ & $78 \%$ & $4 \%$ & - & $-15 \%$ & $-31 \%$ & $-30 \%$ \\
\hline \multicolumn{11}{|c|}{ Meat/replacers } \\
\hline \multirow{4}{*}{ Burgers } & $\operatorname{SLPF}(n=3)$ & $\begin{array}{c}155 \\
(155-157)\end{array}$ & $\begin{array}{c}0.7 \\
(0.4-0.8)\end{array}$ & $\begin{array}{c}25 \\
(16-31)\end{array}$ & $\begin{array}{c}27.9 \\
(274-289)\end{array}$ & $\begin{array}{c}2.2 \\
(20-27)\end{array}$ & $\begin{array}{c}7.4 \\
\end{array}$ & $\begin{array}{c}4.1 \\
(2-49)\end{array}$ & 2.7 & 0.7 \\
\hline & Peoular $(n-4)$ & $\begin{array}{c}(150-15 /) \\
249\end{array}$ & $\begin{array}{c}(0.4-0.0) \\
22\end{array}$ & $\begin{array}{c}(10-51) \\
1100\end{array}$ & $\begin{array}{c}(27.4-28.9) \\
5\end{array}$ & $\begin{array}{c}(2.0-2.7) \\
1.2\end{array}$ & $\begin{array}{c}\text { Unly i value } \\
0.4\end{array}$ & $\begin{array}{c}(2.7-4.9) \\
15.7\end{array}$ & $\begin{array}{c}(1.5-3.2) \\
7.4\end{array}$ & $\begin{array}{c}(0.5-0.8) \\
0.9\end{array}$ \\
\hline & $\operatorname{Reguiar}(n=4)$ & $(226-280)$ & $(17.0-25.6)$ & $(850-1280)$ & $(1.2-10.0)$ & $(<0.5-3.3)$ & $(0.0-0.7)$ & $(13.0-17.4)$ & $(6.2-7.9)$ & $(0.7-1.1)$ \\
\hline & \% Difference & $-38 \%$ & $-97 \%$ & $-98 \%$ & $458 \%$ & $83 \%$ & $1750 \%$ & $-74 \%$ & $-64 \%$ & $-22 \%$ \\
\hline \multirow{4}{*}{ Fish } & $\operatorname{SLPF}(n=1)$ & 138 & 1.1 & 38 & 27.8 & 1.1 & 10.3 & 0.2 & 0 & 2.3 \\
\hline & Dorat & 98 & 22.5 & 1125 & 0.3 & 0.1 & 0.2 & 0.8 & 0.3 & 0.2 \\
\hline & $\operatorname{Regular}(n=2)$ & (98-98) & $(21.8-23.1)$ & (1090-1155) & $(0.0-0.5)$ & $(0.0-0.1)$ & $(0.0-0.3)$ & $(0.3-1.2)$ & $(0.1-0.4)$ & $(0.1-0.3)$ \\
\hline & $\%$ Difference & $41 \%$ & $-95 \%$ & $-97 \%$ & $9167 \%$ & $1000 \%$ & $5050 \%$ & $-75 \%$ & $-100 \%$ & $1050 \%$ \\
\hline \multirow{4}{*}{ Sausages } & $\operatorname{SLPF}(n=3)$ & $\begin{array}{c}146 \\
(140-150)\end{array}$ & $\begin{array}{c}0.8 \\
(0.6-0.9)\end{array}$ & $\begin{array}{c}33 \\
(29-38)\end{array}$ & $\begin{array}{c}27.8 \\
(27.1-28.4)\end{array}$ & $\begin{array}{c}4.1 \\
(1.8-6.3)\end{array}$ & No values & $\begin{array}{c}4 \\
(3.1-4.6)\end{array}$ & $\begin{array}{c}2.6 \\
(2.1-2.8)\end{array}$ & $\begin{array}{c}0.8 \\
(0.7-0.9)\end{array}$ \\
\hline & Reoular $(n-6)$ & 260 & 16.2 & 810 & 7.3 & 3 & 1.9 & 18 & 7.9 & 1.4 \\
\hline & $\operatorname{Regular}(n=6)$ & $(200-309)$ & $(14.0-21.2)$ & $(700-1060)$ & $(0.7-16.0)$ & $(0.7-6.5)$ & $(1.0-3.8)$ & $(13.0-24.5)$ & $(5.0-13.2)$ & $(1.0-1.9)$ \\
\hline & $\%$ Difference & $-44 \%$ & $-95 \%$ & $-96 \%$ & $281 \%$ & $37 \%$ & - & $-78 \%$ & $-67 \%$ & $-43 \%$ \\
\hline \multicolumn{11}{|c|}{ Breakfast and cereal bars } \\
\hline \multirow{4}{*}{ Breakfast bar } & $\operatorname{SLPF}(n=4)$ & $\begin{array}{c}472 \\
\end{array}$ & 0.3 & 17 & 67.2 & 30.5 & No values & 22.3 & 14.1 & 0.5 \\
\hline & & $\begin{array}{c}(464-48) \\
413\end{array}$ & $\begin{array}{c}(0.2-0.5) \\
7.5\end{array}$ & $\begin{array}{c}(12-25) \\
375\end{array}$ & $\begin{array}{c}(65.5-68.7) \\
62.7\end{array}$ & $\begin{array}{c}(26.2-33.5) \\
24.6\end{array}$ & 5.9 & $\begin{array}{c}(20.8-24.4) \\
13.9\end{array}$ & $\begin{array}{c}(13.0-15.4) \\
4.1\end{array}$ & $\begin{array}{l}0.5-0.6) \\
0.4\end{array}$ \\
\hline & $\operatorname{Regular}(n=8)$ & $(372-485)$ & $(4.7-15.0)$ & $(235-750)$ & $(42.0-74.0)$ & $(19.0-36.1)$ & $(4.3-10.0)$ & $(6.6-26.0)$ & $(0.8-10.4)$ & $\begin{array}{c}0.4 \\
(0.0-0.9)\end{array}$ \\
\hline & $\%$ Difference & $14 \%$ & $-96 \%$ & $-95 \%$ & $7 \%$ & $24 \%$ & - & $60 \%$ & $244 \%$ & $25 \%$ \\
\hline \multirow{5}{*}{$\begin{array}{c}\text { Breakfast cereal } \\
\text { (dried) }\end{array}$} & $\operatorname{SLPF}(n=3)$ & 380 & 0.4 & 12 & 92.5 & 35.6 & 1.6 & 0.9 & 0.8 & 0.2 \\
\hline & & $(374-385)$ & $(0.2-0.6)$ & $(6-22)$ & $(91.0-93.6)$ & $(34.0-38.9)$ & $(1.1-2.3)$ & $(0.7-1.1)$ & $(0.6-0.9)$ & $(0.2-0.2)$ \\
\hline & $\operatorname{Regular}(n=6)$ & 385 & 7.7 & 385 & 78.8 & 19.7 & 5 & 3.3 & 0.7 & 0.7 \\
\hline & & $(378-398)$ & $(6.0-9.4)$ & $(300-470)$ & $(72.0-84.0)$ & $(8.0-35.0)$ & $(2.5-8.9)$ & $(0.9-4.6)$ & $(0.2-0.9)$ & $(0.2-1.1)$ \\
\hline & \% Difference & $-1 \%$ & $-95 \%$ & $-97 \%$ & $17 \%$ & $81 \%$ & $-68 \%$ & $-73 \%$ & $14 \%$ & $-71 \%$ \\
\hline
\end{tabular}


Table A1. Cont.

\begin{tabular}{|c|c|c|c|c|c|c|c|c|c|c|}
\hline \multicolumn{2}{|c|}{ Product } & $\begin{array}{c}\text { Energy (kcal) } \\
\text { per } 100 \mathrm{~g}\end{array}$ & $\begin{array}{l}\text { Protein }(\mathrm{g}) \\
\text { per } 100 \mathrm{~g}\end{array}$ & $\begin{array}{l}\text { Phenylalanine } \\
\text { (mg) per } 100 \mathrm{~g}\end{array}$ & $\begin{array}{l}\text { Total } \\
\text { Carbohydrate } \\
\text { (g) per } 100 \mathrm{~g}\end{array}$ & $\begin{array}{l}\text { Carbohydrate of } \\
\text { Which Is Sugars }(\mathrm{g}) \\
\text { per } 100 \mathrm{~g} \text { per } 100 \mathrm{~g}\end{array}$ & $\begin{array}{l}\text { Fibre }(\mathrm{g}) \text { per } \\
\quad 100 \mathrm{~g}\end{array}$ & $\begin{array}{l}\text { Total Fat (g) } \\
\text { per } 100 \mathrm{~g}\end{array}$ & $\begin{array}{l}\text { Saturated } \\
\text { Fat }(\mathrm{g}) \text { per } \\
100 \mathrm{~g}\end{array}$ & $\begin{array}{c}\text { Salt }(g) \\
\text { per } 100 \mathrm{~g}\end{array}$ \\
\hline \multirow{4}{*}{ Fruit bar } & $\operatorname{SLPF}(n=1)$ & 424 & 0.6 & 16 & 72 & 38 & 3.6 & 14 & 7 & 0.3 \\
\hline & Regular $(n=2)$ & 358 & 4.1 & 205 & 69.7 & 34 & 3.1 & 7.2 & 2.8 & 0.5 \\
\hline & $\operatorname{Regular}(n=2)$ & $(351-364)$ & $(3.9-4.2)$ & $(195-210)$ & $(67.0-72.3)$ & $(33.0-34.9)$ & $(2.4-3.8)$ & $(6.0-8.3)$ & $(2.5-3.0)$ & $(0.4-0.6)$ \\
\hline & \% Difference & $18 \%$ & $-85 \%$ & $-92 \%$ & $3 \%$ & $12 \%$ & $16 \%$ & $94 \%$ & $150 \%$ & $-40 \%$ \\
\hline \multirow{5}{*}{$\begin{array}{l}\text { Hot breakfast } \\
\text { cereal (with } \\
\text { water) }\end{array}$} & $\operatorname{SLPF}(n=4)$ & 137 & 0.1 & 4 & 31.5 & 8.3 & Novalues & 1.1 & 0.7 & 0.2 \\
\hline & & $(130-147)$ & $(0.0-0.1)$ & $(2-6)$ & $(30.0-33.5)$ & $(6.5-10.0)$ & No values & $(1.0-1.4)$ & $(0.6-1.0)$ & $(0.1-0.2)$ \\
\hline & Pocular $(n-4)$ & 97 & 3.8 & 190 & 16.6 & 5.6 & 1.6 & 1.3 & 0.3 & 0.1 \\
\hline & $\operatorname{Regular}(n=4)$ & $(91-104)$ & $(3.4-4.3)$ & $(170-215)$ & $(16.0-17.4)$ & $(4.1-6.3)$ & $(1.1-2.1)$ & $(1.2-1.4)$ & $(0.2-0.3)$ & $(0.1-0.1)$ \\
\hline & \% Difference & $41 \%$ & $-97 \%$ & $-98 \%$ & $90 \%$ & $48 \%$ & - & $-15 \%$ & $133 \%$ & $100 \%$ \\
\hline \multicolumn{11}{|c|}{ Snacks } \\
\hline \multirow{5}{*}{ Biscuits/cookies } & $\operatorname{SLPF}(n=9)$ & 488 & 0.5 & 10 & 75.1 & 17.5 & 0.7 & 20.5 & 8.8 & 0.3 \\
\hline & $\operatorname{SLPF}(n=9)$ & $(476-506)$ & $(0.2-0.7)$ & $(1-27)$ & $(68.2-84.0)$ & $(14.9-25.6)$ & $(0.5-1.0)$ & $(15.0-25.0)$ & $(7.3-10.4)$ & $(0.0-0.7)$ \\
\hline & & 499 & 5.6 & 280 & 62.6 & 26.3 & 2.6 & 24.8 & 12.6 & 0.7 \\
\hline & $\operatorname{Regular}(n=14)$ & $(475-531)$ & $(4.1-7.1)$ & $(205-355)$ & $(48.0-72.6)$ & $(16.2-38.1)$ & $(1.3-5.5)$ & $(19.0-32.1)$ & $(2.8-19.0)$ & $(0.5-1.1)$ \\
\hline & \% Difference & $-2 \%$ & $-91 \%$ & $-96 \%$ & $20 \%$ & $-33 \%$ & $-73 \%$ & $-17 \%$ & $-30 \%$ & $-57 \%$ \\
\hline \multirow{4}{*}{ Cake } & $\operatorname{SLPF}(n=3)$ & $\begin{array}{c}372 \\
(372-372)\end{array}$ & $\begin{array}{c}0.2 \\
(0.2-0.2)\end{array}$ & $\begin{array}{c}6 \\
6-6\end{array}$ & $\begin{array}{c}58 \\
(58,0-580)\end{array}$ & $\begin{array}{c}33.5 \\
(33.5-33.5)\end{array}$ & 1.3 & $\begin{array}{c}15.2 \\
(152-152)\end{array}$ & $\begin{array}{c}7.6 \\
(76-76)\end{array}$ & $\begin{array}{c}0.7 \\
(07-0.7)\end{array}$ \\
\hline & & $\begin{array}{c}(3 / 2-3 / 2) \\
422\end{array}$ & $\begin{array}{c}(0.2-0.2) \\
4.3\end{array}$ & $\begin{array}{l}(b-6) \\
215\end{array}$ & $\begin{array}{c}(58.0-58.0) \\
55.2\end{array}$ & $\begin{array}{c}(33.5-33.5) \\
27.4\end{array}$ & & $\begin{array}{c}(15.2-15.2) \\
21.2\end{array}$ & $\begin{array}{c}(7.6-/ .6) \\
2.1\end{array}$ & $\begin{array}{c}(0.7-0.7) \\
0.3\end{array}$ \\
\hline & $\operatorname{Regular}(n=2)$ & $(393-450)$ & $(4.1-4.4)$ & $(205-220)$ & $(52.4-58.0)$ & $(22.7-32.0)$ & No values & $(19.4-23.0)$ & $(1.8-2.4)$ & $(0.1-0.4)$ \\
\hline & \% Difference & $-12 \%$ & $-95 \%$ & $-97 \%$ & $5 \%$ & $22 \%$ & - & $-28 \%$ & $262 \%$ & $133 \%$ \\
\hline \multirow{5}{*}{ Chocolate } & & 566 & 0.3 & 12 & 54.2 & 51.1 & 5.4 & 37.7 & 27.7 & 0 \\
\hline & $\operatorname{SLPF}(n=2)$ & (549-583) & $(0.2-0.4)$ & $(<10-14)$ & $(47.0-61.4)$ & $(43.0-59.1)$ & $(0.9-9.8)$ & $(33.4-42)$ & $(25-30.4)$ & $(0.0-0.0)$ \\
\hline & Roculan (1) 0 ) & 540 & 7 & 350 & 56.5 & 55.7 & 2.1 & 31.2 & 18.8 & 0.2 \\
\hline & Kegular $(n=2)$ & $(534-546)$ & $(6.7-7.3)$ & $(335-365)$ & $(56.0-57.0)$ & $(55.4-56)$ & Only 1 value & $(30.0-32.4)$ & $(18.0-19.6)$ & $(0.2-0.3)$ \\
\hline & \% Difference & $5 \%$ & $-96 \%$ & $-97 \%$ & $-4 \%$ & $-8 \%$ & $157 \%$ & $21 \%$ & $47 \%$ & $-100 \%$ \\
\hline \multirow{5}{*}{ Crackers } & SLPF $(n-3)$ & 446 & 0.5 & 12 & 77.3 & 2.5 & 1 & 14.7 & 6.9 & 1.5 \\
\hline & SLPF $(n=3)$ & $(444-450)$ & $(0.4-0.5)$ & $(10-17)$ & $(77.0-78.0)$ & $(1.5-3.0)$ & $(0.9-1.1)$ & $(14.6-15.0)$ & $(6.9-7.0)$ & $(1.3-1.6)$ \\
\hline & $\operatorname{Regular}(n=6)$ & 426 & 8.7 & 435 & 72.6 & 5.1 & 3.5 & 11 & 3.6 & 1.8 \\
\hline & Keguiar $(n=6)$ & $(360-470)$ & $(5.7-10.1)$ & $(285-505)$ & $(66.4-82.6)$ & $(1.6-15.0)$ & $(2.5-4.2)$ & $(1.0-19.6)$ & $(0.2-8.7)$ & $(1.2-2.4)$ \\
\hline & \% Difference & $5 \%$ & $-94 \%$ & $-97 \%$ & $6 \%$ & $-51 \%$ & $-71 \%$ & $34 \%$ & $92 \%$ & $-17 \%$ \\
\hline \multirow{5}{*}{ Crisps } & $\operatorname{SLPF}(n=4)$ & 437 & 0.3 & 16 & 77.8 & $<0.1$ & No values & 16.2 & 2.3 & 3.2 \\
\hline & & $(369-465)$ & $(0.1-0.5)$ & $(8-22)$ & $(77.5-78.4)$ & $(<0.1-<0.1)$ & No values & $(16.0-16.6)$ & $(2.3-2.3)$ & $(2.6-4.2)$ \\
\hline & Becular $(n-8)$ & 519 & 5.8 & 290 & 52.8 & 1.8 & 4 & 30.8 & 3.4 & 1.5 \\
\hline & $\operatorname{Regular}(n=8)$ & $(499-536)$ & $(3.6-6.7)$ & $(180-335)$ & $(51.0-57.1)$ & $(0.2-3.6)$ & $(3.1-4.3)$ & $(28.7-33.0)$ & $(2.5-8.9)$ & $(1.0-2.5)$ \\
\hline & \% Difference & $-16 \%$ & $-95 \%$ & $-94 \%$ & $47 \%$ & $-95 \%$ & - & $-47 \%$ & $-32 \%$ & $113 \%$ \\
\hline
\end{tabular}


Table A1. Cont.

\begin{tabular}{|c|c|c|c|c|c|c|c|c|c|c|}
\hline \multicolumn{2}{|c|}{ Product } & $\begin{array}{c}\text { Energy (kcal) } \\
\text { per } 100 \mathrm{~g}\end{array}$ & $\begin{array}{c}\text { Protein }(\mathrm{g}) \\
\text { per } 100 \mathrm{~g}\end{array}$ & $\begin{array}{l}\text { Phenylalanine } \\
\text { (mg) per } 100 \mathrm{~g}\end{array}$ & $\begin{array}{l}\text { Total } \\
\text { Carbohydrate } \\
\text { (g) per } 100 \mathrm{~g}\end{array}$ & $\begin{array}{l}\text { Carbohydrate of } \\
\text { Which Is Sugars }(\mathrm{g}) \\
\text { per } 100 \mathrm{~g} \text { per } 100 \mathrm{~g}\end{array}$ & $\begin{array}{l}\text { Fibre }(\mathrm{g}) \text { per } \\
\quad 100 \mathrm{~g}\end{array}$ & $\begin{array}{l}\text { Total Fat }(\mathrm{g}) \\
\text { per } 100 \mathrm{~g}\end{array}$ & $\begin{array}{c}\text { Saturated } \\
\text { Fat }(\mathrm{g}) \text { per } \\
100 \mathrm{~g}\end{array}$ & $\begin{array}{c}\text { Salt }(\mathrm{g}) \\
\text { per } 100 \mathrm{~g}\end{array}$ \\
\hline \multirow{4}{*}{$\begin{array}{l}\text { Crispbread } \\
\text { crackers * }\end{array}$} & $\operatorname{SLPF}(n=1)$ & 388 & 0.3 & 6 & 88 & 0.1 & 2.6 & 3.3 & 1.8 & 0.6 \\
\hline & Reoular $(n-2)$ & 441 & 9.9 & 495 & 67.5 & 1.5 & 3.5 & 13.9 & 6.4 & 1.3 \\
\hline & $\operatorname{Reguiar}(n=2)$ & $(440-442)$ & $(9.7-10.0)$ & $(485-500)$ & $(67.2-67.7)$ & $(1.4-1.6)$ & $(3.1-3.8)$ & $(13.5-14.3)$ & $(6.2-6.5)$ & $(1.3-1.3)$ \\
\hline & \% Difference & $-12 \%$ & $-97 \%$ & $-99 \%$ & $30 \%$ & $-93 \%$ & $-26 \%$ & $-76 \%$ & $-72 \%$ & $-54 \%$ \\
\hline \multirow{4}{*}{$\begin{array}{l}\text { French toast } \\
\text { crackers }\end{array}$} & $\operatorname{SLPF}(n=1)$ & 413 & $<1.0$ & 30 & 76.3 & 5.2 & 7 & 10 & 5.6 & 0.1 \\
\hline & Regular $(n=2)$ & 440 & 8 & 400 & 75 & 18.3 & 2.9 & 11.4 & 5.1 & 0.4 \\
\hline & Keguiar $(n=2)$ & $(440-440)$ & $(7.8-8.2)$ & $(390-410)$ & $(74.5-75.5)$ & $(18.0-18.6)$ & $(2.8-2.9)$ & $(11.0-11.7)$ & $(5.0-5.1)$ & $(0.4-0.4)$ \\
\hline & $\%$ Difference & $-6 \%$ & $-99 \%$ & $-93 \%$ & $2 \%$ & $-72 \%$ & $141 \%$ & $-13 \%$ & $10 \%$ & $-75 \%$ \\
\hline \multirow{4}{*}{ Hazelnut spread } & $\operatorname{SLPF}(n=1)$ & 347 & 0.5 & 19 & 42 & 7 & 0.5 & 19.6 & 10.6 & 0.2 \\
\hline & $\operatorname{Regular}(n=2)$ & 549 & 6.3 & 315 & 54.8 & 53.2 & 3.2 & 33.5 & 8.9 & 0.1 \\
\hline & Kegular $(n=2)$ & $(539-558)$ & $(6.3-6.3)$ & $(315-315)$ & $(52.0-57.5)$ & $(50.0-56.3)$ & $(3.2-3.2)$ & $(30.9-36.0)$ & $(7.2-10.6)$ & $(0.1-0.1)$ \\
\hline & \% Difference & $-37 \%$ & $-92 \%$ & $-94 \%$ & $-23 \%$ & $-87 \%$ & $-84 \%$ & $-41 \%$ & $19 \%$ & $100 \%$ \\
\hline \multirow{4}{*}{ Rusks } & $\operatorname{SLPF}(n=1)$ & 388 & 0.3 & 4 & 68.8 & 24.5 & 0.3 & 12.1 & 7.6 & 0.3 \\
\hline & Doculan ( -7$)$ & 410 & 7.8 & 390 & 75.2 & 26.5 & 4.6 & 7.6 & 3.6 & 0.2 \\
\hline & Keguiar $(n=2)$ & $(405-414)$ & $(7.0-8.5)$ & $(350-425)$ & $(71.2-79.2)$ & $(24.0-29.0)$ & $(2.1-7.0)$ & $(7.2-8)$ & $(3.1-4.0)$ & $(0.0-0.4)$ \\
\hline & \% Difference & $-5 \%$ & $-96 \%$ & $-99 \%$ & $-9 \%$ & $-8 \%$ & $-93 \%$ & $59 \%$ & $111 \%$ & $50 \%$ \\
\hline \multicolumn{11}{|c|}{ Desserts } \\
\hline \multirow{4}{*}{ Dessert pot } & $\operatorname{SLPF}(n=2)$ & 181 & 0 & $<4$ & 27 & 12.1 & No values & 8.2 & 0.7 & 0.1 \\
\hline & & (181-181) & $(0.0-0.0)$ & $(<4-<4)$ & $(26.9-27.1)$ & $(11.7-12.5)$ & & $(8.1-8.2)$ & $(0.6-0.8)$ & $(0.1-0.1)$ \\
\hline & Regular $(n=4)$ & 133 & 3.7 & 185 & 17.6 & 14.8 & 0.2 & 5.3 & 3.4 & 0.1 \\
\hline & $\%$ Difference & $\begin{array}{c}(114-181) \\
36 \%\end{array}$ & $\begin{array}{l}(3.3-4.3) \\
-100 \%\end{array}$ & $\begin{array}{c}(165-215) \\
-98 \%\end{array}$ & $\begin{array}{c}(15.4-20.0) \\
53 \%\end{array}$ & $\begin{array}{c}(13.0-20.0) \\
-18 \%\end{array}$ & - & $\begin{array}{c}(3.4-9.3) \\
55 \%\end{array}$ & $\begin{array}{c}(2.6-5.1) \\
-79 \%\end{array}$ & $\begin{array}{c}(0.1-0.2) \\
0 \%\end{array}$ \\
\hline \multirow{5}{*}{$\begin{array}{c}\text { Flavoured } \\
\text { desserts (dried } \\
\text { powder) }\end{array}$} & & & & & & & & & & 0.9 \\
\hline & $\operatorname{SLPF}(n=4)$ & $(400-409)$ & $(0.1-0.9)$ & $(4-50)$ & $(89.3-95.3)$ & $(46.1-51.5)$ & No values & $(2.2-5.4)$ & $(2.1-4.3)$ & $(0.1-3.1)$ \\
\hline & Regular $(n=7)$ & 424 & 2.2 & 110 & 77.9 & 35.8 & 0.1 & 11.4 & 9.4 & 1.2 \\
\hline & & $(352-485)$ & $(0.4-4.6)$ & $(20-230)$ & $(71.4-87.5)$ & $(0.1-58.3)$ & $(0.0-0.2)$ & $(0.2-20.9)$ & $(0.1-17.5)$ & $(0.0-2.4)$ \\
\hline & \% Difference & $-4 \%$ & $-82 \%$ & $-82 \%$ & $17 \%$ & $35 \%$ & - & $-61 \%$ & $-62 \%$ & $-25 \%$ \\
\hline \multirow{5}{*}{ Jelly (dried) } & $\operatorname{SLPF}(n=2)$ & 356 & 0 & $<2$ & 88 & 87 & No values & 0 & 0 & 0 \\
\hline & & $(356-356)$ & $(0.0-0.0)$ & $(<2-<2)$ & $(88.0-88.0)$ & $(87.0-87.0)$ & No values & $(0.0-0.0)$ & $(0.0-0.0)$ & $(0.0-0.0)$ \\
\hline & $\operatorname{Regular}(n=4)$ & 332 & 2.8 & 140 & 81 & 74.6 & No values & 0 & 0 & 0.3 \\
\hline & Kegular $(n=4)$ & $(296-375)$ & $(0.0-5.5)$ & $(0-275)$ & $(68.5-94.5)$ & (57.4-94.5) & No values & $(0.0-0.0)$ & $(0.0-0.0)$ & $(0.02-0.5)$ \\
\hline & \% Difference & $7 \%$ & $-100 \%$ & $-99 \%$ & $9 \%$ & $17 \%$ & - & $0 \%$ & $0 \%$ & $-100 \%$ \\
\hline \multirow{5}{*}{ Rice pudding } & $\operatorname{SLPF}(n=4)$ & 121 & 0.1 & 6 & 26.4 & 2.3 & No values & 1.6 & 1.5 & 0 \\
\hline & & (119-122) & $(0.1-0.2)$ & $(5-8)$ & $(26.3-26.6)$ & $(1.3-2.8)$ & & $(1.4-1.8)$ & $(1.3-1.7)$ & $(0.0-0.0)$ \\
\hline & Regular $(n=6)$ & 102 & 3 & 150 & 17.6 & 11.1 & 0.3 & 2.2 & 1.2 & 0.2 \\
\hline & Keguiar $(n-0)$ & $(96-107)$ & $(2.7-3.4)$ & $(135-170)$ & $(15.8-18.8)$ & $(8.9-13.3)$ & $(0.0-0.5)$ & $(1.9-2.6)$ & $(1.0-1.5)$ & $(0.1-0.2)$ \\
\hline & \% Difference & $19 \%$ & $-97 \%$ & $-96 \%$ & $50 \%$ & $-79 \%$ & - & $-27 \%$ & $25 \%$ & $-100 \%$ \\
\hline
\end{tabular}


Table A1. Cont.

\begin{tabular}{|c|c|c|c|c|c|c|c|c|c|c|}
\hline \multicolumn{2}{|c|}{ Product } & $\begin{array}{c}\text { Energy (kcal) } \\
\text { per } 100 \mathrm{~g}\end{array}$ & $\begin{array}{l}\text { Protein }(\mathrm{g}) \\
\text { per } 100 \mathrm{~g}\end{array}$ & $\begin{array}{l}\text { Phenylalanine } \\
\text { (mg) per } 100 \mathrm{~g}\end{array}$ & $\begin{array}{l}\quad \text { Total } \\
\text { Carbohydrate } \\
\text { (g) per } 100 \mathrm{~g}\end{array}$ & $\begin{array}{l}\text { Carbohydrate of } \\
\text { Which Is Sugars }(\mathrm{g}) \\
\text { per } 100 \mathrm{~g} \text { per } 100 \mathrm{~g}\end{array}$ & $\begin{array}{l}\text { Fibre }(\mathrm{g}) \text { per } \\
\quad 100 \mathrm{~g}\end{array}$ & $\begin{array}{l}\text { Total Fat }(\mathrm{g}) \\
\text { per } 100 \mathrm{~g}\end{array}$ & $\begin{array}{l}\text { Saturated } \\
\text { Fat }(\mathrm{g}) \text { per } \\
100 \mathrm{~g}\end{array}$ & $\begin{array}{c}\text { Salt }(g) \\
\text { per } 100 \mathrm{~g}\end{array}$ \\
\hline \multirow{4}{*}{ Yogurt ** } & $\operatorname{SLPF}(n=1)$ & 61 & 0.1 & 2 & 8 & 1 & 1 & 2.6 & 1 & 0.1 \\
\hline & $\operatorname{Reoular}(n=2)$ & 75 & 4.4 & 220 & 4.5 & 4.5 & \multirow{3}{*}{$\begin{array}{c}\text { No values } \\
-\end{array}$} & 4.1 & 2.7 & 0.1 \\
\hline & Regular $(n=2)$ & $(68-82)$ & $(3.7-5.1)$ & $(185-255)$ & $(3.4-5.6)$ & $(3.4-5.6)$ & & $(3.7-4.5)$ & $(2.4-2.9)$ & $(0.1-0.2)$ \\
\hline & $\%$ Difference & $-19 \%$ & $-98 \%$ & $-99 \%$ & $78 \%$ & $-78 \%$ & & $-37 \%$ & $-63 \%$ & $0 \%$ \\
\hline \multicolumn{11}{|c|}{ Other snacks/meals } \\
\hline \multirow{4}{*}{$\begin{array}{c}\text { Cheese sauce } \\
\text { (prepared) }\end{array}$} & $\operatorname{SLPF}(n=1)$ & 86 & 0.8 & 13 & 18.4 & 0.9 & No value & 1 & 0.7 & 0.9 \\
\hline & & 76 & 1.4 & 70 & 9.5 & 1.5 & 0.5 & 3.4 & 2.4 & 0.9 \\
\hline & $\operatorname{Regular}(n=2)$ & $(65-86)$ & $(1.2-1.6)$ & $(60-80)$ & $(9.2-9.8)$ & $(1.4-1.5)$ & $(<0.5-0.5)$ & $(2.0-4.8)$ & $(1.1-3.6)$ & $(0.7-1.0)$ \\
\hline & \% Difference & $13 \%$ & $-43 \%$ & $-81 \%$ & $94 \%$ & $-40 \%$ & - & $-71 \%$ & $-71 \%$ & $0 \%$ \\
\hline \multirow{4}{*}{ Potato cakes } & $\operatorname{SLPF}(n=1)$ & 165 & 0.8 & 46 & 30.9 & 0.6 & No value & 3.7 & 0.5 & 0.6 \\
\hline & Poculan $(n-2)$ & 190 & 2.3 & 115 & 22.5 & 0.8 & 2 & 9.6 & 1.2 & 0.6 \\
\hline & $\operatorname{Regular}(n=2)$ & $(175-205)$ & $(1.9-2.6)$ & $(95-130)$ & $(21.0-23.9)$ & $(<0.5-1.2)$ & $(1.8-2.1)$ & $(8.6-10.5)$ & $(1.1-1.2)$ & $(0.5-0.7)$ \\
\hline & \% Difference & $-13 \%$ & $-65 \%$ & $-60 \%$ & $37 \%$ & $-25 \%$ & - & $-61 \%$ & $-58 \%$ & $0 \%$ \\
\hline \multirow{4}{*}{$\begin{array}{c}\text { Potato } \\
\text { pots/Smash }\end{array}$} & $\operatorname{SLPF}(n=3)$ & 112 & 0.5 & 25 & 22.8 & 0.6 & No values & 1.8 & 1 & 0.9 \\
\hline & & (111-115) & $(0.4-0.5)$ & $(23-27)$ & $(22.7-22.9)$ & $(0.4-0.8)$ & & $(1.6-2.1)$ & $(0.9-1.1)$ & $(0.9-0.9)$ \\
\hline & $\operatorname{Regular}(n=4)$ & $\begin{array}{c}82 \\
(75-87)\end{array}$ & 1.8 & 90 & 13.9 & 1 & 1.3 & 2 & 1.1 & 0.3 \\
\hline & $\%$ Difference & $\begin{array}{c}(75-87) \\
37 \%\end{array}$ & $\begin{array}{c}(1.6-2.1) \\
-72 \%\end{array}$ & $\begin{array}{c}(80-105) \\
-72 \%\end{array}$ & $\begin{array}{c}(12.0-15.4) \\
64 \%\end{array}$ & $\begin{array}{c}(0.7-1.4) \\
-40 \%\end{array}$ & $\begin{array}{c}(1.1-1.3) \\
-\end{array}$ & $\begin{array}{c}(1.5-2.2) \\
-10 \%\end{array}$ & $\begin{array}{c}(0.8-1.4) \\
-9 \%\end{array}$ & $\begin{array}{c}(0.1-0.5) \\
200 \%\end{array}$ \\
\hline \multirow{5}{*}{ Soup } & & 37 & 0.2 & 2 & 7.5 & 1.5 & & & & 0.6 \\
\hline & $\operatorname{SLPF}(n=4)$ & $(35-40)$ & $(0.2-0.4)$ & $(1-2)$ & $(6.6-8.5)$ & $(1.4-1.8)$ & No value & $(0.3-0.8)$ & $(0.1-0.4)$ & $\begin{array}{l}0.0 \\
(0.4-0.8)\end{array}$ \\
\hline & Reoular $(n-8)$ & 37 & 0.7 & 35 & 6.2 & 2 & 0.4 & 1 & 0.6 & 0.5 \\
\hline & $\operatorname{Regular}(n=8)$ & $(26-48)$ & $(<0.5-1.1)$ & $(<25-55)$ & $(4.9-8.3)$ & $(<0.5-4.5)$ & $(0.1-0.5)$ & $(0.4-1.9)$ & $(0.1-1.4)$ & $(0.5-0.6)$ \\
\hline & \% Difference & $0 \%$ & $-71 \%$ & $-94 \%$ & $21 \%$ & $-25 \%$ & - & $-40 \%$ & $-50 \%$ & $20 \%$ \\
\hline
\end{tabular}

* Compared to cream crackers; ${ }^{* *}$ Compared to plain/natural yogurt. 


\section{References}

1. Van Wegberg, A.M.J.; MacDonald, A.; Ahring, K.; Bélanger-Quintana, A.; Blau, N.; Bosch, A.M.; Burlina, A.; Campistol, J.; Feillet, F.; Giżewska, M.; et al. The complete European guidelines on phenylketonuria: Diagnosis and treatment. Orphanet J. Rare Dis. 2017, 12, 162. Available online: https://ojrd.biomedcentral. com/articles/10.1186/s13023-017-0685-2 (accessed on 20 May 2020). [CrossRef] [PubMed]

2. Ford, S.; O'Driscoll, M.; MacDonald, A. Living with phenylketonuria: Lessons from the PKU community. Mol. Genet. Metab. Rep. 2018, 17, 57-63. [CrossRef] [PubMed]

3. Rocha, J.C.; MacDonald, A.; Trefz, F. Is overweight an issue in phenylketonuria? Mol. Genet. Metab. 2013, 110 (Suppl.), S18-S24. [CrossRef] [PubMed]

4. Rocha, J.C.; MacDonald, A. Dietary intervention in the management of phenylketonuria: Current perspectives. Pediatr. Health Med. Ther. 2016, 7, 155-163. [CrossRef]

5. Cochrane, B.; Schwahn, B.; Galloway, P.; Robinson, P.; Gerasimidis, K. A questionnaire survey on the usage of low protein staple foods by people with phenylketonuria in Scotland. J. Hum. Nutr. Diet. 2014, 27, 533-541. [CrossRef] [PubMed]

6. European Commission. Commission Directive 1999/21/EC on dietary foods for special medical purposes. Off. J. Eur. Union 1999, 42, 29-36.

7. Advisory Committee on Borderline Substances. Nutritional Legislation and Other Guidance with Which Products Must Comply. Available online: https://assets.publishing.service.gov.uk/government/uploads/ system/uploads/attachment_data/file/792996/Appendix3.pdf (accessed on 16 February 2020).

8. Food Standards Agency. Food Information Regulations 2014: Summary Guidance for Food Business Operators and Enforcement Officers in Scotland, Wales and Northern Ireland. Available online: https://www.food.gov.uk/ sites/default/files/media/document/fir\$-\$guidance2014.pdf (accessed on 16 February 2020).

9. Department of Health. The Medical Food (England) Regulations. Statutory Instrument No. 845. 2000. Available online: http://www.legislation.gov.uk/uksi/2000/845/made (accessed on 16 February 2020).

10. Pena, M.J.; Almeida, M.F.; Van Dam, E.; Ahring, K.; Bélanger-Quintana, A.; Dokoupil, K.; Gokmen-Ozel, H.; Lammardo, A.M.; MacDonald, A.; Robert, M.; et al. Special low protein foods for phenylketonuria: Availability in Europe and an examination of their nutritional profile. Orphanet J. Rare Dis. 2015, 10, 162. Available online: https://ojrd.biomedcentral.com/articles/10.1186/s13023-015-0378-7 (accessed on 20 May 2020). [CrossRef]

11. Moretti, F.; Pellegrini, N.; Salvatici, E.; Rovelli, V.; Banderali, G.; Radaelli, G.; Scazzina, F.; Giovannini, M.; Verduci, E. Dietary glycemic index, glycemic load and metabolic profile in children with phenylketonuria. Nutr. Metab. Cardiovasc. Dis. 2017, 27, 176-182. [CrossRef]

12. Dixon, M.; MacDonald, A.; White, F.; Stafford, J. Disorders of amino acid metabolism, organic acidaemias, and urea cycle disorders. In Clinical Paediatric Dietetics, 4th ed.; Shaw, V., Ed.; Wiley Blackwell: Chichester, UK, 2015; pp. 381-525.

13. Karam, P.E.; Majdalani, M.N.; Daher, R.T.; Barhoumi, A.; Yazbeck, N. Cardiovascular disease biomarkers in patients with inborn errors of protein metabolism: A pilot study. J. Hum. Nutr. Diet. 2015, 28, 344-349. [CrossRef]

14. Rocha, J.C.; van Spronsen, F.J.; Almeida, M.F.; Soares, G.; Quelhas, D.; Ramos, E.; Guimarães, J.T.; Borges, N. Dietary treatment in phenylketonuria does not lead to increased risk of obesity or metabolic syndrome. Mol. Genet. Metab. 2012, 107, 659-663. [CrossRef]

15. Evans, M.; Truby, H.; Boneh, A. The relationship between dietary intake, growth and body composition in phenylketonuria. Mol. Genet. Metab. 2017, 122, 36-42. [CrossRef] [PubMed]

16. Robertson, L.V.; Mcstravick, N.; Ripley, S.; Weetch, E.; Donald, S.; Adam, S.; Micciche, A.; Boocock, S.; MacDonald, A. Body mass index in adult patients with diet-treated phenylketonuria. J. Hum. Nutr. Diet. 2013, 26 (Suppl. 1), 1-6. [CrossRef] [PubMed]

17. Verduci, E.; Banderali, G.; Moretti, F.; Lassandro, C.; Cefalo, G.; Radaelli, G.; Salvatici, E.; Giovannini, M. Diet in children with phenylketonuria and risk of cardiovascular disease: A narrative overview. Nutr. Metab. Cardiovasc. Dis. 2016, 26, 171-177. [CrossRef] [PubMed]

18. Dhaka, V.; Gulia, N.; Ahlawat, K.S.; Khatkar, B.S. Trans fats-sources, health risks and alternative approach-A review. J. Food Sci. Technol. 2011, 48, 534-541. [CrossRef] [PubMed]

19. Klonoff, D.C. Replacements for trans fats-Will there be an oil shortage? J. Diabetes Sci. Technol. 2007, 1, 415-422. [CrossRef] [PubMed] 
20. Hosseinpour-Niazi, S.; Mirmiran, P.; Hosseini-Esfahani, F.; Azizi, F. Is the metabolic syndrome inversely associates with butter, non-hydrogenated- and hydrogenated-vegetable oils consumption: Tehran lipid and glucose study. Diabetes Res. Clin. Pract. 2016, 112, 20-29. [CrossRef]

21. Mach, F.; Baigent, C.; Catapano, A.L.; Koskinas, K.C.; Casula, M.; Badimon, L.; Chapman, M.J.; De Backer, G.G.; Delgado, V. 2019 ESC/EAS Guidelines for the management of dyslipidaemias: Lipid modification to reduce cardiovascular risk: The Task Force for the management of dyslipidaemias of the European Society of Cardiology (ESC) and European Atherosclerosis Society (EAS). Eur. Heart J. 2020, 41, 111-188. [CrossRef]

22. Boateng, L.; Ansong, R.; Owusu, W.B.; Steiner-Asiedu, M. Coconut oil and palm oil's role in nutrition, health and national development: A review. Ghana Med. J. 2016, 50, 189-196.

23. Montoya, C.; Cochard, B.; Flori, A.; Cros, D.; Lopes, R.; Cuellar, T.; Espeout, S.; Syaputra, I.; Villeneuve, P.; Pina, M.; et al. Genetic architecture of palm oil fatty acid composition in cultivated oil palm (Elaeis guineensis Jacq.) compared to its wild relative E. oleifera (H.B.K) Cortés. PLoS ONE 2014, 9, e95412. Available online: https://journals.plos.org/plosone/article?id=10.1371/journal.pone.0095412 (accessed on 21 May 2020). [CrossRef]

24. Mozaffarian, D. Dairy foods, obesity and metabolic health: The role of the food matrix compared with single nutrients. Adv. Nutr. 2019, 10,917S-923S. [CrossRef]

25. Soltanizadeh, N.; Mirmoghtadaie, L. Strategies used in production of phenylalanine-free foods for PKU management. Compr. Rev. Food Sci. Food Saf. 2014, 13, 287-299. [CrossRef]

26. Schober, T.J. Manufacture of Gluten-Free Specialty Breads and Confectionery Products. In Gluten-Free Food Science and Technology; Gallagher, E., Ed.; Blackwell Publishing Ltd.: Oxford, UK, 2009; pp. 130-180.

27. Henry, C.; Lightowler, H.; Kendall, F.; Storey, M. The impact of the addition of toppings/fillings on the glycaemic response to commonly consumed carbohydrate foods. Eur. J. Clin. Nutr. 2006, 60, 763-769. [CrossRef] [PubMed]

28. Couce, M.L.; Sánchez-Pintos, P.; Vitoria, I.; De Castro, M.J.; Aldámiz-Echevarría, L.; Correcher, P.; Fernández-Marmiesse, A.; Roca, I.; Hermida, A.; Martínez-Olmos, M.; et al. Carbohydrate status in patients with phenylketonuria. Orphanet J. Rare Dis. 2018, 13, 103. Available online: https://ojrd.biomedcentral.com/ articles/10.1186/s13023-018-0847-x (accessed on 21 May 2020). [CrossRef] [PubMed]

29. Ormazabal, V.; Nair, S.; Elfeky, O.; Aguayo, C.; Salomon, C.; Zuñiga, F. Association between insulin resistance and the development of cardiovascular disease. Cardiovasc. Diabetol. 2018, 17, 122. Available online: https://cardiab.biomedcentral.com/articles/10.1186/s12933-018-0762-4\#citeas (accessed on 27 May 2020). [CrossRef] [PubMed]

30. El Khoury, D.; Balfour-Ducharme, S.; Joye, I.J. A review on the gluten-free diet: Technological and nutritional challenges. Nutrients 2018, 10, 1410. Available online: https://www.mdpi.com/2072-6643/10/10/1410 (accessed on 21 May 2020). [CrossRef]

31. Viebke, C.; Al-Assaf, S.; Phillips, G.O. Food hydrocolloids and health claims. Bioact. Carbohydr. Diet. Fibre 2014, 4, 101-114. [CrossRef]

32. Trefz, K.F.; Muntau, A.C.; Kohlscheen, K.M.; Altevers, J.; Jacob, C.; Braun, S.; Greiner, W.; Jha, A.; Jain, M.; Alvarez, I.; et al. Clinical burden of illness in patients with phenylketonuria (PKU) and associated comorbidities-A retrospective study of German health insurance claims data. Orphanet J. Rare Dis. 2019, 14, 181. Available online: https://ojrd.biomedcentral.com/articles/10.1186/s13023\$-\$019\$-\$1153\$-\$y (accessed on 21 May 2020). [CrossRef]

33. Burton, B.K.; Bradford Jones, K.; Cederbaum, S.; Rohr, F.; Waisbren, S.; Irwin, D.E.; Kim, G.; Lilienstein, J.; Alvarez, I.; Jurecki, E.; et al. Prevalence of comorbid conditions among adult patients diagnosed with phenylketonuria. Mol. Genet. Metab. 2018, 125, 228-234. [CrossRef]

34. Azabdaftari, A.; van der Giet, M.; Schuchardt, M.; Hennermann, J.B.; Plöckinger, U.; Querfeld, U. The cardiovascular phenotype of adult patients with phenylketonuria. Orphanet J. Rare Dis. 2019, 14, 213. Available online: https://ojrd.biomedcentral.com/articles/10.1186/s13023-019-1188-0 (accessed on 21 May 2020). [CrossRef]

35. Hermida-Ameijeiras, A.; Crujeiras, V.; Roca, I.; Calvo, C.; Leis, R.; Couce, M.L. Arterial stiffness assessment in patients with phenylketonuria. Medicine 2017, 96, e9322. Available online: https://journals.lww. com/md-journal/Fulltext/2017/12220/Arterial_stiffness_assessment_in_patients_with.94.aspx (accessed on 21 May 2020). 
36. Rocha, J.C.; van Rijn, M.; van Dam, E.; Ahring, K.; Bélanger-Quintana, A.; Dokoupil, K.; Gokmen-Ozel, H.; Lammardo, A.M.; Robert, M.; Heidenborg, C.; et al. Weight Management in Phenylketonuria: What Should Be Monitored? Ann. Nutr. Metab. 2016, 68, 60-65. [CrossRef] [PubMed]

37. Albersen, M.; Bonthuis, M.; de Roos, N.M.; van den Hurk, D.A.M.; Carbasius Weber, E.; Hendriks, M.M.W.B.; de Sain-van der Velden, M.G.M.; de Koning, T.J.; Visser, G. Whole body composition analysis by the BodPod air-displacement plethysmography method in children with phenylketonuria shows a higher body fat percentage. J. Inherit. Metab. Dis. 2010, 33 (Suppl. 3), S283-S288. [CrossRef] [PubMed]

38. Belanger-Quintana, A.; Martínez-Pardo, M. Physical development in patients with phenylketonuria on dietary treatment: A retrospective study. Mol. Genet. Metab. 2011, 104, 480-484. [CrossRef] [PubMed]

39. Burrage, L.C.; McConnell, J.; Haesler, R.; O’Riordan, M.A.; Sutton, V.R.; Kerr, D.S.; McCandless, S.E. High prevalence of overweight and obesity in females with phenylketonuria. Mol. Genet. Metab. 2012, 107, 43-48. [CrossRef] [PubMed]

40. Doulgeraki, A.; Skarpalezou, A.; Theodosiadou, A.; Monopolis, I.; Schulpis, K. Body composition profile of young patients with phenylketonuria and mild hyperphenylalaninemia. Int. J. Endocrinol. Metab. 2014, 12, e16061. Available online: https://sites.kowsarpub.com/ijem/articles/17675.html (accessed on 21 May 2020). [CrossRef]

41. Evans, S.; Ford, S.; Adam, S.; Adams, S.; Ash, J.; Ashmore, C.; Caine, G.; Carruthers, R.; Cawtherley, S.; Chahal, S.; et al. Development of national consensus statements on food labelling interpretation and protein allocation in a low phenylalanine diet for PKU. Orphanet J. Rare Dis. 2019, 14, 2. Available online: https: //ojrd.biomedcentral.com/articles/10.1186/s13023\$-\$018\$-\$0950\$-\$z (accessed on 21 May 2020). [CrossRef]

42. MacDonald, A.; Lilburn, M.; Davies, P.; Evans, S.; Daly, A.; Hall, S.K.; Hendriksz, C.; Chakrapani, A.; Lee, P. 'Ready to drink' protein substitute is easier is for people with phenylketonuria. J. Inherit. Metab. Dis. 2006, 29, 526-531. [CrossRef]

43. MacDonald, A.; Lilburn, M.; Cochrane, B.; Davies, P.; Daly, A.; Asplin, D.; Hall, S.K.; Cousins, A.; Chakrapani, A.; Robinson, P.; et al. A new, low-volume protein substitute for teenagers and adults with phenylketonuria. J. Inherit. Metab. Dis. 2004, 27, 127-135. [CrossRef]

44. Evans, S.; Adam, S.; Adams, S.; Allen, H.; Ashmore, A.; Bailey, S.; Banks, J.; Churchill, H.; Cochrane, B.; Cook, J.; et al. Uniformity of food protein interpretation amongst dietitians for patients with phenylketonuria (PKU): 2020 UK National Consensus Statements. Nutrients, under Review.

45. Piepoli, M.F.; Abreu, A.; Albus, C.; Ambrosetti, M.; Brotons, C.; Catapano, A.L.; Corra, U.; Cosyns, B.; Deaton, C.; Graham, I.; et al. Update on cardiovascular prevention in clinical practice: A position paper of the European Association of Preventive Cardiology of the European Society of Cardiology. Eur. J. Prev. Cardiol. 2020, 27, 181-205. [CrossRef]

46. Zmora, N.; Suez, J.; Elinav, E. You are what you eat: Diet, health and the gut microbiota. Nat. Rev. 2019, 16, 35-56. [CrossRef]

(C) 2020 by the authors. Licensee MDPI, Basel, Switzerland. This article is an open access article distributed under the terms and conditions of the Creative Commons Attribution (CC BY) license (http://creativecommons.org/licenses/by/4.0/). 